\title{
Seepage Investigation and Selected Hydrologic Data for the Escalante River Drainage Basin, Garfield and Kane Counties, Utah, 1909-2002
}

By Dale E. Wilberg and Bernard J. Stolp

U.S. GEOLOGICAL SURVEY

Scientific Investigations Report 2004-5233

Prepared in cooperation with the

U. S. DEPARTMENT OF THE INTERIOR, BUREAU OF LAND MANAGEMENT, GRAND STAIRCASE-ESCALANTE NATIONAL MONUMENT

Salt Lake City, Utah 


\section{U.S. DEPARTMENT OF THE INTERIOR}

GALE A. NORTON, Secretary

\section{U.S. GEOLOGICAL SURVEY}

Charles G. Groat, Director

Any use of trade, product, or firm names in this publication is for descriptive purposes only and does not imply endorsement by the U.S. Government.

For additional information write to:

Copies of this report can be purchased from:

District Chief

U.S. Geological Survey 2329 West Orton Circle

Salt Lake City, Utah 84119

http://ut.water.usgs.gov

\author{
U.S. Geological Survey \\ Branch of Information Services \\ Building 810 \\ Box 25286, Denver Federal Center \\ Denver, C0 80225-0286 \\ 1-888-ASK-USGS
}




\section{CONTENTS}

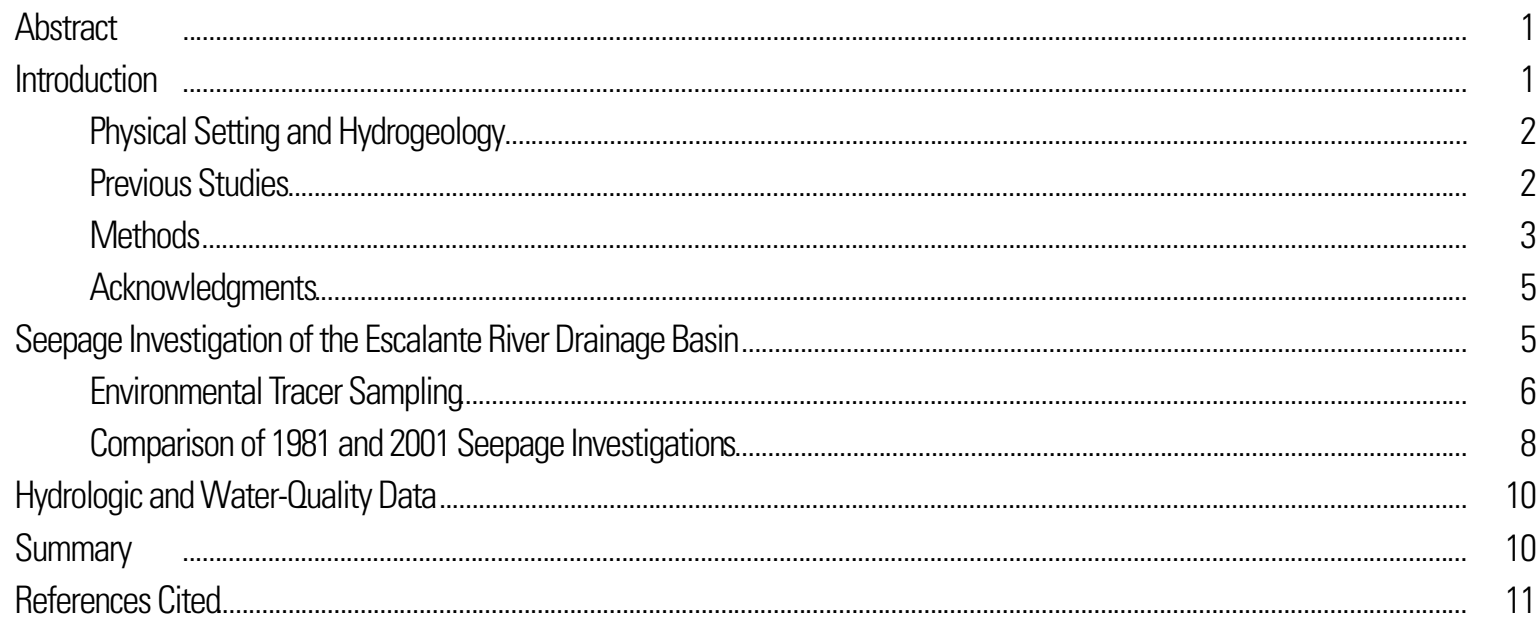

\section{FIGURES}

Plate 1. Map showing location of selected surface-water sites and springs, Escalante River drainage basin, Garfield and Kane Counties, Utah...................................................................................... plate.pdf

Figure 1. Map showing instantaneous discharge and specific-conductance measurements made on October 23 and 24, 2001, along the Escalante River, Garfield and Kane Counties, Utah

Figure 2. Graph showing streamflow on October 21, 1981, and October 23, 2001, along the Escalante River, Garfield and Kane Counties, Utah.. 


\section{TABLES}

Table 1. Records of selected surface-water sites and springs in the Escalante River drainage basin, Garfield and Kane Counties, Utah

Table 2. Error analysis for data collected during seepage investigation along 15 reaches of the Escalante River between gaging station 09337500 and Stevens Canyon, Garfield and Kane Counties, Utah, October 2001

Table 3. Discharge, specific conductance, and temperature of water measured during seepage investigations along the Escalante River and tributaries, Garfield and Kane Counties, Utah, October 1981 and October 2001

Table 4. Field measurements of specific conductance and water temperature from selected surfacewater sites and springs in the Escalante River drainage basin, Garfield and Kane Counties, Utah, 1951-2002

Table 5. Tritium concentration in water from selected surface-water sites and springs along the Escalante River and tributaries, Garfield and Kane Counties, Utah, 2001

Table 6. Chlorofluorocarbon concentration in water from selected surface-water sites and springs along the Escalante River and tributaries, Garfield and Kane Counties, Utah, 2001

Table 7. Selected data for gaging stations in the Escalante River drainage basin, Garfield and Kane Counties, 1909-2002

Table 8. Field measurements of specific conductance and water temperature at gaging station at Pine Creek near Escalante (09337000, site 9), Garfield County, Utah, 1971-91

Table 9. Field measurements of specific conductance and water temperature at gaging station at Escalante River near Escalante (09337500, site 10), Garfield County, Utah, 1969-2001

Table 10. Physical properties and results of chemical analyses for water from the gaging station at Escalante River near Escalante (09337500, site 10), Garfield County, Utah, 1969-72

Table 11. Physical properties and results of chemical analyses for water from the gaging station at Escalante River at mouth (09339500, site 64), Kane County, Utah, 1951-53.

Table 12. Physical properties and results of chemical analyses for water from selected surfacewater sites and springs in the Escalante River drainage basin, Garfield and Kane Counties, Utah, 1981-2002 


\section{CONVERSION FACTORS, DATUMS, AND ABBREVIATED WATER-QUALITY UNITS}

\begin{tabular}{rcl}
\hline Multiply & By & To obtain \\
\hline cubic foot per second $\left(\mathrm{ft}^{3} / \mathrm{s}\right)$ & 0.02832 & cubic meter per second \\
& 448.8 & gallon per minute \\
foot $(\mathrm{ft})$ & 0.3048 & meter \\
mile $(\mathrm{mi})$ & 1.609 & kilometer \\
square mile $\left(\mathrm{mi}^{2}\right)$ & 2.59 & square kilometer \\
\hline
\end{tabular}

Water temperature is reported in degrees Celsius $\left({ }^{\circ} \mathrm{C}\right)$ and degrees Fahrenheit $\left({ }^{\circ} \mathrm{F}\right)$ and may be converted by using the following equations:

$$
\begin{gathered}
{ }^{\circ} \mathrm{F}=1.8\left({ }^{\circ} \mathrm{C}\right)+32 \\
{ }^{\circ} \mathrm{C}=\left({ }^{\circ} \mathrm{F}-32\right) / 1.8 .
\end{gathered}
$$

Vertical coordinate information is referenced to the National Geodetic Vertical Datum of 1929 (NGVD 29). Horizontal coordinate information is referenced to the North American Datum of 1927 (NAD 27).

Concentrations of chemical constituents in water are reported either in milligrams per liter (mg/L) or micrograms per liter $(\mu \mathrm{g} / \mathrm{L})$. Milligrams per liter and micrograms per liter are units expressing the concentration of chemical constituents in solution as mass (grams) of solute per unit volume (liter) of water. A liter of water is assumed to weigh 1 kilogram, except for brines or water at high temperatures because of significant changes in the density of the water. For concentrations less than $7,000 \mathrm{mg} / \mathrm{L}$ or $7,000,000 \mu \mathrm{g} / \mathrm{L}$, the numerical value is the same as for concentrations in parts per million or parts per billion, respectively.

Specific conductance is reported in microsiemens per centimeter $(\mu \mathrm{S} / \mathrm{cm})$ at 25 degrees Celsius. Tritium concentration in water is reported as tritium units (TU). The ratio of 1 atom of tritium to $10^{18}$ atoms of hydrogen is equal to 1 TU. Chlorofluorocarbons (CFCs) are measured in picomoles per kilogram (pmoles $/ \mathrm{kg}$ ), which is equivalent to parts per quadrillion. 


\section{NUMBERING SYSTEM USED FOR HYDROLOGIC-DATA SITES IN UTAH}

The system of numbering hydrologic-data sites in Utah is based on the cadastral land-survey system of the U.S. Government. The number describes its position in the land net. The land-survey system divides the State into four quadrants separated by the Salt Lake Base Line and the Salt Lake Meridian. These quadrants are designated by the uppercase letters A, B, C, and D, indicating the northeast, northwest, southwest, and southeast quadrants, respectively. Numbers designating the township and range, in that order, follow the quadrant letter, and all three are enclosed in parentheses. The number after the parentheses indicates the section and is followed by three lowercase letters indicating the quarter section, the quarter-quarter section, and the quarter-quarter-quarter section-generally 10 acres for a regular section ${ }^{1}$. The lowercase letters a, $\mathrm{b}, \mathrm{c}$, and d indicate, respectively, the northeast, northwest, southwest, and southeast quarters of each subdivision. The number after the letters is the serial number of the well or spring within the 10-acre tract. When the serial number is not preceded by a letter, the number designates a well. When the serial number is preceded by an "S," the number designates a spring. Thus, (D-35-5)9bda-1 designates the first hydrologic-data site visited in the northeast $1 / 4$ of the southeast $1 / 4$ of the northwest $1 / 4$ of section 9 , T. 35 S., R. 5 E.

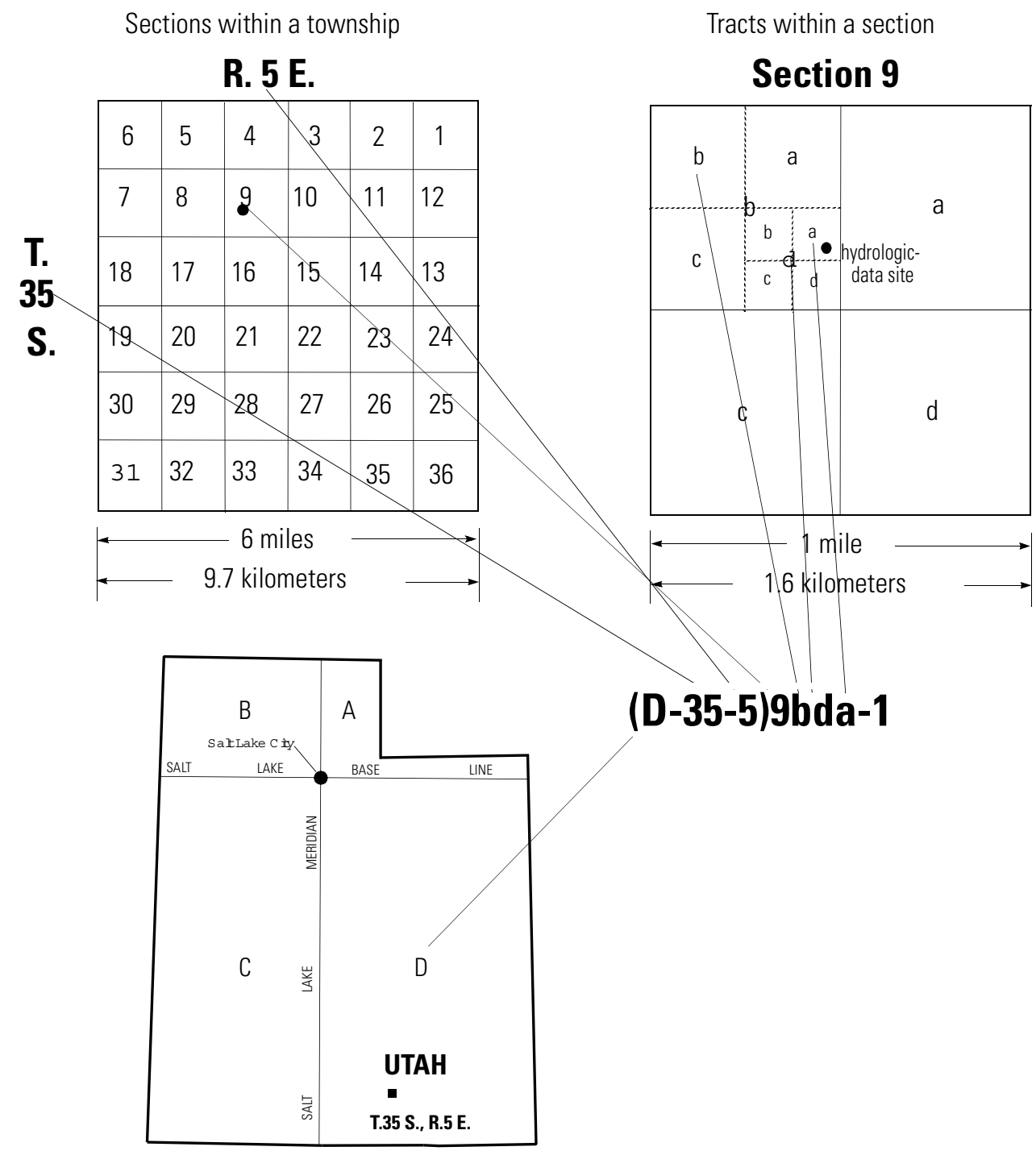

${ }^{1}$ Although the basic land unit, the section, is theoretically 1 square mile, many sections are irregular in size and shape. Such sections are subdivided into 10-acre tracts, generally beginning at the southeast corner, and the surplus or shortage is taken up in the tracts along the north and west sides of the section. 


\title{
Seepage Investigation and Selected Hydrologic Data for the Escalante River Drainage Basin, Garfield and Kane Counties, Utah, 1909-2002
}

\author{
By Dale E. Wilberg and Bernard J. Stolp
}

\section{ABSTRACT}

This report contains the results of an October 2001 seepage investigation conducted along a reach of the Escalante River in Utah extending from the U.S. Geological Survey streamflow-gaging station near Escalante to the mouth of Stevens Canyon. Discharge was measured at 16 individual sites along 15 consecutive reaches. Total reach length was about 86 miles. A reconnaissance-level sampling of water for tritium and chlorofluorcarbons was also done. In addition, hydrologic and water-quality data previously collected and published by the U.S. Geological Survey for the 2,020-square-mile Escalante River drainage basin was compiled and is presented in 12 tables. These data were collected from 64 surface-water sites and 28 springs from 1909 to 2002.

None of the 15 consecutive reaches along the Escalante River had a measured loss or gain that exceeded the measurement error. All discharge measurements taken during the seepage investigation were assigned a qualitative rating of accuracy that ranged from 5 percent to greater than 8 percent of the actual flow. Summing the potential error for each measurement and dividing by the maximum of either the upstream discharge and any tributary inflow, or the downstream discharge, determined the normalized error for a reach. This was compared to the computed loss or gain that also was normalized to the maximum discharge. A loss or gain for a specified reach is considered significant when the loss or gain (normalized percentage difference) is greater than the measurement error (normalized percentage error). The percentage difference and percentage error were normalized to allow comparison between reaches with different amounts of discharge.

\section{INTRODUCTION}

Grand Staircase-Escalante National Monument was established in 1996 for the protection, preservation, and scientific study of the natural and cultural resources. In keeping with those goals, the U.S. Geological Survey (USGS) is working cooperatively with the U.S. Bureau of Land Management (BLM) to identify and understand the hydrologic system within the monument. Specifically, this includes studying (1) baseline characteristics and variability, (2) regional and subregional surface- and ground-water systems, and (3) site-specific processes and interaction.

Much of the land in the Escalante River drainage basin is managed by the Grand Staircase-Escalante National Monument (pl. 1). The Escalante River is the largest perennial stream in the monument and creates important aquatic and riparian habitat. A seepage investigation of the river was conducted to better understand the hydrologic connection to the surrounding ground-water system. The seepage investigation was designed to determine (1) if large amounts of surface water in the Escalante River are lost or gained, (2) where those losses or gains occurred, (3) the amount of losses or gains and if they are significant, and (4) which rock units are involved. If specific reaches of the river have significantly large losses or gains, then those reaches could be the focus of future, detailed seepage investigations. Similarly, if specific rock units are large sources or sinks of surface water, then those units could be the focus of future detailed seepage investigations.

This report contains the results of the October 2001 seepage investigation along the Escalante River and comparison with an October 1981 seepage 
investigation. It also includes a compilation of all hydrologic and water-quality data collected by the USGS within the Escalante River drainage basin from 1909 to 2002.

Discharge measurements, seepage loses and gains, results of environmental tracer analyses, and the historical data for 64 surface-water sites and 28 springs (pl. 1) are presented in a series of tables located at the end of the report. All sites presented in this report are organized in downstream order in table 1 . For each site, any additional tables that contain data for the site and the original source of the data are listed in table 1 . The site identification (site ID) is a unique number that is needed for the data to be accessed electronically within the USGS National Water Information System (NWIS) and is based on the latitude-longitude of a site or, in the case of a streamflow gage, the station number.

\section{Physical Setting and Hydrogeology}

The area of the Escalante River drainage basin is approximately $2,020 \mathrm{mi}^{2}$ as measured from the point where the Escalante River formerly joined the Colorado River, now covered by Lake Powell. The drainage basin is located within the High Plateau section and the Canyon Lands section of the Colorado Plateau physiographic province (Hunt, 1974). The high-altitude, lava-capped Aquarius Plateau, which is bounded by the Paunsagunt Fault on the west, is in the High Plateau section. The eroded sandstone canyons of the Escalante River and its tributaries are in the Canyon Lands section. Altitude ranges from about 11,200 ft near the headwaters of East Fork Boulder Creek on Boulder Mountain to 3,700 ft at lake level when Lake Powell is full. Altitude of data-collection sites ranges from 9,315 ft at the East Fork Boulder Creek gage (USGS stream gage 09338000) to $3,380 \mathrm{ft}$ at the former site of the Escalante River at mouth gage (USGS stream gage 09339500). Average basin altitude is 6,400 $\mathrm{ft}$. In addition to the canyons of the Escalante River and its tributaries, major geographic features are the (1) Aquarius Plateau and Boulder Mountain on the north where perennial tributaries such as Birch, North, Pine, Mamie, Death Hollow, Sand, Calf, Boulder, and Deer Creeks originate; (2) Escalante Mountains on the west that include Griffin Top and Barney Top, where drainage divides separate the Paria, East Fork of Sevier, Fremont, and the Escalante Rivers; (3) Kaiparowits Plateau and Fiftymile Mountain to the southwest, south, and southeast; and (4) Waterpocket Fold and Circle Cliffs to the east and northeast (pl. 1).

Two geohydrologic units crop out in the canyon of the Escalante River along the channel reach where the October 2001 seepage investigation was done, the Navajo aquifer of Jurassic age and the underlying Chinle-Moenkopi confining unit of Triassic age (Freethey and Cordy, 1991, p. C12-C21). The Navajo aquifer primarily is composed of massive, very fine- to medium-grained, well sorted, crossbedded sandstones of the Wingate Sandstone, Navajo Sandstone, and Page Sandstone, and interbedded fluvial sandstone, siltstone, and mudstone of the Kayenta Formation (Freethey and Cordy, 1991, p. C17). The Page Sandstone does not crop out at river level. The Chinle-Moenkopi confining unit is composed of fluvial and lacustrine sandstone, siltstone, shale, and bentonitic mudstone of the undifferentiated Chinle Formation (Hackman and Wyant, 1973, sheet 1). The Moenkopi Formation does not crop out in the area of seepage investigation.

Massive cliffs and deeply incised canyons are cut into the Navajo and Wingate Sandstones and the stepped slopes of Kayenta Formation from Pine Creek at Mile 0 to below Twentyfive Mile Wash near Mile 55. The Chinle Formation first crops out at Mile 55 along the outside bends on the north side of the river and crops out continuously from about Mile 59 ( $1 \mathrm{mi}$ above Moody Creek) to about Mile 84 (2 mi above Stevens Canyon). Maximum incision into the soft Chinle Formation by the Escalante River occurs between Mile 68 and Mile 77. Removal of the easily erodable Chinle Formation undercuts the support of the overlying Wingate Sandstone cliffs, which causes them to collapse and the canyon to widen. Large talus and rockslide deposits, primarily composed of boulders from the Wingate Sandstone, and rotational slump block deposits, composed of Chinle Formation, are well developed in this reach of the river.

\section{Previous Studies}

Records of surface-water discharge data for the following USGS stream gages (station number in parentheses) in the Escalante River drainage basin are published in the following USGS Water-Supply Papers (WSP): WSP 1313 (U.S. Geological Survey, 1954) for the period before 1950 for Escalante River (09337500, called Escalante Creek before 1913); WSP 1733 (U.S. Geological Survey, 1964) for 1950-60 for North Creek 
(09335500), Birch Creek near Escalante (09336000), Birch Creek at mouth (09336500), Pine Creek (09337000), Escalante River (09337500), East Fork Boulder Creek (09338000), East Fork Deer Creek (09338500), Boulder Creek (09339000), and Escalante River at mouth (09339500); and WSP 1925 (U.S. Geological Survey, 1970) for 1961-65 and WSP 2125 (U.S. Geological Survey, 1973) for 1966-70 for Pine Creek (09337000) and East Fork Boulder Creek (09338000). Annual maximum discharges are published in WSP 1313 (U.S. Geological Survey, 1954), WSP 1925 (U.S. Geological Survey, 1970), and WSP 2125 (U.S. Geological Survey, 1973) for creststage partial-record stations at Birch Creek near Escalante (09336000), Upper Valley Creek near Escalante (09336400), East Fork Deer Creek near Boulder (09338500), Deer Creek near Boulder (09338900), and Twentymile Wash near Escalante (09339200). Surface-water records of active gages in the Escalante River drainage basin have been published annually since 1962 in USGS publications referred to as Surface Water Records of Utah (U.S. Geological Survey, 1962-65) and Water Resources Data for Utah (U.S. Geological Survey, 1966-82; ReMillard and others, 1983-96; Herbert and others, 1997-2002; Wilberg and others, 2003).

Cloudburst floods in Utah were described by Woolley (1946) for 1850-1938 and by Butler and Marsel (1972) for 1939-69. Both reports contain descriptions of floods in the Escalante River drainage basin. A summary of maximum discharges in streams in Utah was authored by Whitaker (1969) and includes data collected at partial-record stations described above. Equations for estimating streamflow characteristics including average discharge and annual maximum 1-, 7-, and 15-day mean discharges for recurrence intervals of 10,50 , and 100 years were determined at or near the gages in the Escalante River drainage basin by Christiansen and others (1986). Equations for estimating the magnitude and flood frequency of 2-, 5-, 10-, 25-, 50-, and 100-year peak discharges at ungaged sites for areas of Utah and the southwestern United States, including areas in the Escalante River drainage basin, were developed by Thomas and Lindskov (1983), and Thomas and others (1997).

Water-quality analyses and seepage investigation data were collected by the USGS in support of various ground-water and surface-water studies. These studies were cooperatively funded by the USGS and either the
State of Utah, Department of Natural Resources; or the U.S. Department of the Interior, Bureau of Land Management. Some data republished in this report originally were interpreted or published in Price (1978 and 1979), Plantz (1983 and 1985), Blanchard (1986), and Wilberg (1995).

Descriptions of geology are contained in Doelling and others (2000). A historic perspective of the geography and geology of the area is contained in Gregory and Moore (1931).

\section{Methods}

Most of the Escalante River corridor is remote and difficult to access. To make the necessary streamflow measurements for the seepage investigation, approach to the river was by foot or helicopter. The river between the Escalante gage and Horse Canyon, informally referred to as the upper canyon, was accessed by hiking, either overland to the rim and then descending into the canyon or by hiking along the river corridor. Access below Horse Canyon was by helicopter, which was authorized by Glen Canyon National Recreation Area.

In May 2001 an unfunded float trip of the Escalante River along the 79-mi reach between Calf Creek and Cow Canyon on Lake Powell (which was at an altitude of 3,668 ft on May 24, 2001) was organized to collect water samples, to assess general logistics that would be required for the seepage investigation, and to explore a relatively remote river canyon. The float trip was facilitated by runoff from an above-average snowpack in the headwaters of the Escalante River drainage basin. Twenty-six water samples were measured in the field for temperature and specific conductance, 5 samples were collected for laboratory analysis of common constituents, 10 samples were collected for tritium analysis, and 5 samples were collected for analysis of chlorofluorcarbons (CFCs). During the October 2001 seepage investigation, eight additional water samples were collected from selected sites along the Escalante River and one from Twentyfive Mile Wash for analysis of CFCs.

By using the streamflow data gathered during the seepage investigation, losses (-) or gains for each of the 15 reaches between the Escalante gage and Stevens Canyon (table 2) were determined according to the following equation: 
Computation of loss (-) or gain $=Q_{d s}-\left(Q_{u s}+Q_{i n}-\right.$
$\left.Q_{\text {diversion }}\right)$

where:

$Q_{d s}=$ discharge measured at a downstream site;

$Q_{u s}=$ discharge measured at an upstream site;

$Q_{\text {in }}=$ discharge measured at a tributary inflow (if a tributary is not mentioned in table 3 , then it had no flow); and

$Q_{\text {diversion }}=$ discharge of a diversion (there were no diversions along any reaches measured during this seepage investigation).

A technique developed by Wilberg and others (2001) was used to determine if the difference between discharge measured at upstream and downstream sites in a specified reach exceeds the error associated with the measurement of discharge at those sites. A significant loss or gain is determined when the loss or gain exceeds the error associated with measurement of discharge. Measurements of discharge made during this seepage investigation generally were rated as good or fair, which means in the opinion of the hydrographer, the amount of water measured was within 5 percent of the actual discharge for a measurement rated good or within 8 percent for a measurement rated fair. These ratings are based on subjective evaluation of objective factors that could affect the accuracy of the measurement. The factors include number and distribution of vertical sections where velocity is measured, average velocity, uniformity of flow, regularity and firmness of channel bottom, steadiness of stage and discharge during the measurement, and presence or absence of ice, wind, or debris in the flow that could affect the ability of the current meter to accurately measure the current velocity (C.W. Boning, U.S. Geological Survey, written commun., 1993). When measuring discharges of less than about 1 or 2 $\mathrm{ft}^{3} / \mathrm{s}$, shallow water depths can place the velocity meter too close to the channel bottom, which can cause the velocity to be underestimated (Rantz and others, 1982, p. 132, 135, and 144). Standard USGS practice is for hydrographers to assign qualitative ratings of accuracy to individual discharge measurements-excellent, good, fair, and poor.

Each specified reach, which is defined as the portion of channel between two discharge measurement sites, is normalized to the maximum discharge of either the upstream measurement site plus any inflow, or the discharge at the downstream site plus any diversions. This is computed by using the following equations:

$$
\left(N_{d} \%\right)=\frac{Q_{d s}-\left(Q_{u s}+Q_{\text {in }}-Q_{\text {diversion }}\right)}{\operatorname{Max} Q_{(u s+\text { inflow }, d s+\text { diversions })}} \bullet 100
$$

where:

$N_{d} \%=$ normalized percentage difference;

$Q_{d s}=$ discharge measured at a downstream site;

$Q_{u s}=$ discharge measured at an upstream site;

$Q_{i n}=$ discharge measured at a tributary inflow (if a tributary is not mentioned in table 3 , then it had no flow);

$Q_{\text {diversion }}=$ discharge of a diversion (there were no diversions along any reaches measured during this seepage investigation);

$\operatorname{Max} Q=$ maximum discharge measured at consecutive upstream or downstream sites. Tributary inflows are added to the upstream discharge;

$100=$ conversion to percentage; and the normalized percentage error is:

$\left(N_{e} \%\right)= \pm \frac{\left(a Q_{d s}+a Q_{u s}+\mathrm{a} Q_{\text {in }}+a Q_{\text {diversion }}\right)}{\left(\text { Max } Q_{(\text {us }+ \text { inflow }, \text { ds }+ \text { diversion })}\right)} \cdot 100$

where:

$N_{e} \%=$ normalized percentage error; and

$a=$ accuracy of a discharge measurement as determined by the hydrographer, a determination of how close the measured discharge is to the actual discharge: 2 percent for excellent, 5 percent for good, 8 percent for fair, and greater than 8 percent for poor.

If $Q_{d s}$ is greater than $Q_{u s}$ plus $Q_{i n}$, that is, if more water was measured at the downstream section of the reach than was measured at the upstream section plus any inflow to that reach (equation 1), then the algebraic sign in equations 1,2 , and 3 is plus (+), which signifies a gain. Conversely, if $Q_{d s}$ is less than $Q_{u s}$ plus $Q_{i n}$, then the sign is minus (-), which signifies a loss for that specific reach. A computed loss or gain for a specific reach is considered significant if the normalized percentage difference $\left(N_{d} \%\right)$ is greater than the normalized percentage error $\left(N_{e} \%\right)$. The percentage difference and percentage error were normalized to allow comparison between reaches with different amounts of discharge. 


\section{Acknowledgments}

D. Kip Solomon of the Dissolved Gas Laboratory at the University of Utah donated his services and laboratory facility for the analyses of CFCs. Norman R. Henderson at Glen Canyon National Recreation Area generously provided pickup and delivery of samples, instruments, equipment, and personnel by boat to Bullfrog Marina following the Escalante River reconnaissance trip in May 2001. J. Douglas Powell, Grand Staircase-Escalante National Monument geologist, participated in water sample collection and reconnaissance during the May 2001 Escalante River float trip. Joni Vanderbilt, former Grand Staircase-Escalante National Monument hydrologist, participated in the 2001 seepage investigation and made the Escalante River discharge measurement at Horse Canyon.

\section{SEEPAGE INVESTIGATION OF THE ESCALANTE RIVER DRAINAGE BASIN}

Discharge was measured on October 23 and 24, 2001, during base-flow conditions from the USGS gage on the Escalante River near Escalante to the mouth of Stevens Canyon about 86 mi downstream near the maximum pool level of Lake Powell. Discharge was measured in the Escalante River at 16 individual sites along 15 consecutive reaches. Discharge also was measured or estimated at the mouths of 14 tributaries to the Escalante River. There were no diversions. The seepage investigation was terminated at Stevens Canyon because it represented the end of natural channel conditions not influenced by fluctuating lake levels, which can affect both sedimentation and channel characteristics.

The reach from the Escalante gage to the mouth of The Gulch, a distance of about 28 miles, was investigated on the first day. Discharge was measured at eight cross sections along the Escalante River (seven reaches) and at the mouths of five tributaries (table 3). Discharge was measured at 10 cross sections along the Escalante River (9 reaches) between The Gulch and Stevens Canyon, a distance of about 55 miles, on the second day. Discharge was measured, or estimated if the flows were too small to measure with a current meter, at the mouths of nine tributaries.
Two stage recorders were operated during the seepage investigation to monitor the fluctuations of the Escalante River. The stage recorded at the permanent gage near Escalante (09337500) increased $0.04 \mathrm{ft}$ during the 2-day investigation and the daily mean discharge increased from $4.3 \mathrm{ft}^{3} / \mathrm{s}$ to $4.7 \mathrm{ft}^{3} / \mathrm{s}$. The stage increased $0.08 \mathrm{ft}$ on the day preceding the start of the seepage investigation and the daily mean discharge was $3.2 \mathrm{ft}^{3} / \mathrm{s}$. The significance of this $0.08 \mathrm{ft}$ rise on October 22,2001 , and its potential impact on the seepage investigation is moderated by attenuation downstream, increasing flow in the river as result of tributary inflows, the relatively small amount of discharge associated with the rise, and the fact that the increase ended 12 hours or more before the seepage investigation measurements began, a sufficient amount of time for the increase to transit the reach. A temporary stage recorder was installed on the Escalante River below the mouth of Calf Creek and operated for 65 hours and 45 minutes from October 22, 2001, at 1530 hours to October 25, 2001, at 0915 hours. River stage was recorded at 15-minute intervals. The stage fluctuated $0.04 \mathrm{ft}$ during the operation of the temporary gage and $0.03 \mathrm{ft}$ during the 2-day seepage investigation. The small amount of stage variation and the lack of rising or falling trends indicate that the stage was quite stable. Two discharge measurements on October 23 and 24, 2001, at the temporary gage were 28.1 and $26.5 \mathrm{ft}^{3} / \mathrm{s}$, respectively, and corroborate the relatively stable base-flow conditions.

None of the 15 reaches along the Escalante River between the Escalante gage and Stevens Canyon that were measured during the seepage investigation of October 23 and 24, 2001, had computed losses or gains that exceeded the normalized error $\left(N_{e} \%\right)$ (see Methods section and table 2). This finding does not indicate that losses or gains do not occur, but rather that the losses or gains were of a smaller magnitude than the errors associated with measurements of discharge. The first two reaches from the gage near Escalante (09337500, site 10) to Escalante River above Sand Creek (site 13) had normalized measurement errors that exceeded the normalized percentage difference by less than 2.1 percent (table 2). A loss or gain might have been determined in these reaches if the discharge measurements were rated as good or fair. This was not possible because shallow stream depths created less than ideal measurement conditions. 
Several springs that discharge from the Navajo aquifer in Coyote Gulch and along the lake-affected channel in the reach below the mouth of Coyote Gulch were not investigated during the October 2001 seepage investigation. These springs are located near the contact of the Kayenta Formation and the overlying Navajo Sandstone (table 4, S25-S28) and could hold important indicators about the source and recharge areas, flow paths, time of travel, and quantity of discharge for water-budget estimates. Although there were no significant losses or gains along the Escalante River in October 2001, streamflow increases downstream, primarily from tributary inflow. Discharge and specific-conductance measurements made during the October 2001 seepage investigation are shown in figure 1.

Two speculative reasons that no significant seepage losses or gains were measured and implications regarding the ground- and surface-water systems and their interactions are:

(1) Accretion of flow in the Escalante River between Pine Creek and Boulder Creek is accounted for as inflow from tributaries. This reach includes perennial tributaries that have headwaters in the Aquarius Plateau and is where the Navajo aquifer is in direct contact with the potential recharge area in higher altitudes of the Aquarius Plateau.

(2) Ground-water discharge from the Navajo aquifer does not occur along the channel of the Escalante River but rather along the tributary channels, especially in the canyon upstream of Boulder Creek; therefore, gaining reaches were not determined during seepage investigations along the Escalante River.

Although tributaries to the Escalante River in the canyon upstream of Boulder Creek are assumed to gain water from the Navajo aquifer, primarily from springflow and fractures, the validity of this assumption could be tested by conducting a seepage investigation along a tributary channel. Identification of gaining reaches along any tributary channels could be used to define areas that could be critical to waterresource management. Mamie, Sand, Calf, and Boulder Creeks all have suitable conditions (perennial flow, outcrops of fractured Navajo Sandstone) conducive for seepage investigations. A seepage investigation at three or four sections along Boulder Creek from the town of Boulder to the mouth would be both logistically and hydrologically feasible. Logistically because there is more than one place to access the different reaches of Boulder Creek, 8and hydrologically because of the relatively large (larger than Calf, Sand, or Mamie Creeks) volume of water to measure. Discharge of the Escalante River can sometimes double with the inflow of Boulder Creek, which contributes considerably more discharge than what generally is observed at the town of Boulder.

\section{Environmental Tracer Sampling}

During the May 2001 float trip, water samples were collected from the Escalante River, tributary streams, and springs for analysis of tritium $\left({ }^{3} \mathrm{H}\right)$ and CFCs. In addition, water samples were collected at nine sites for CFC analysis during the seepage investigation in October 2001. These environmental tracers are used to age-date ground water that has recharged the hydrologic system since the early 1950 s. The 2001 sampling was done at a reconnaissance level to evaluate the utility of these tools to better explain surface- and ground-water interaction. Tritium $\left({ }^{3} \mathrm{H}\right)$ is a radioactive isotope of hydrogen that occurs naturally in very small quantities. Concentrations several orders of magnitude larger than background were introduced into the hydrologic cycle during atmospheric (open air) nuclear testing. Atmospheric testing at the Nevada test sites began with the Able test on January 27, 1951, and ended with the Little Feller I test on July 17, 1962 (Dept. of Energy, 2000, p. 24 and 46). As a result, tritium concentrations are useful for determining whether ground water recharged prior to or after 1950. Tritium units (TU) of less than 0.5 generally are considered indicative of water that recharged the ground-water system prior to open-air nuclear testing, thus, prior to 1951. One TU represents one molecule of ${ }^{3} \mathrm{H}^{1} \mathrm{HO}$ in $10^{18}$ molecules of ${ }^{1} \mathrm{H}_{2} \mathrm{O}$.

Samples of surface water collected in Scorpion Gulch, Fools Canyon, and Stevens Canyon (sites 50, 57 , and 61), respectively, are all younger than 50 years (table 5). These samples represent ground-water discharge to the streams and did not contain any obvious components of surface runoff. Surface water represents a mixture of all ground-water sources feeding the stream, and thus can give an indication of average ground-water age for a drainage. On the basis of limited sampling in 2001, the surface water appears to have a component of younger (less than 50 years) ground water. Because the sampled water has been exposed to the atmosphere as it moves from groundwater source to sampling point, there is a potential that 

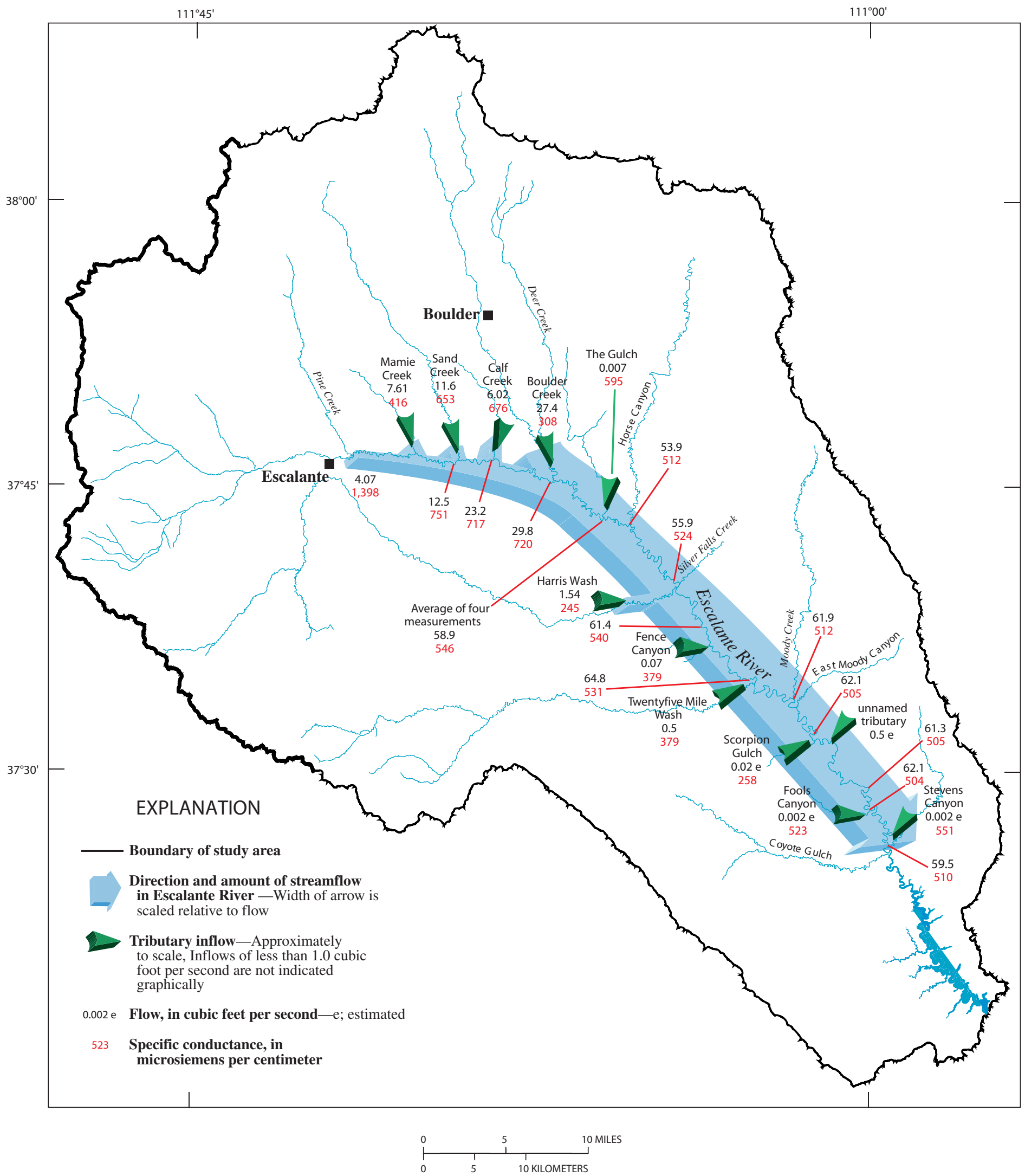

Figure 1. Instantaneous discharge and specific-conductance measurements made on October 23 and 24, 2001, along the Escalante River, Garfield and Kane Counties. 
the tritium in the surface water came from exchange of water molecules in the atmosphere. Current background atmospheric concentrations are about 9 TU. With enough time, exchange will cause all surface water to have a concentration of 9 TU. The exchange, however, is slow and the estimated time that sampled waters were exposed to the atmosphere is on the order of several hours, which potentially could increase the TU concentration by a few tenths $(0.1$ to 0.3$)$.

Water collected from springs that discharge directly from consolidated rock have 0.53 or less TU and indicate an apparent age of greater than 50 years (table 5). With the exception of the spring sampled in Coyote Gulch (S24), these consolidated-rock springs are all located along the Escalante River. These springs have small discharges and a minimal affect on total streamflow. When comparing the age of the springs to those of the tributaries, it seems plausible that flow paths might be deflected toward the incised tributary side canyons. Flow paths toward tributaries appear shorter (younger) and might be a path of least resistance for ground-water discharge. Water from the spring in tuning fork canyon (S23), which discharges from a veneer of talus of Quaternary age, appears less than 50 years old. Given the spring location and the similarity in tritium concentration of the stream in tuning fork canyon (site 52), it is likely that the spring represents stream water that is moving in and out of the adjacent colluvium.

CFCs are synthetic, nontoxic, stable chemical compounds that contain carbon, chlorine, fluorine, and sometimes hydrogen. CFCs were developed in the early 1930s and are used for a variety of domestic and industrial purposes. In the 1970s it was discovered that CFCs deplete stratospheric ozone and considerable effort has been expended to quantify atmospheric concentrations since they were first produced. The solubility of CFCs in water is well known and that makes it possible to use these compounds to determine the apparent age of ground water (apparent because a number of simplifications are used to determine age). Sampling for CFC concentrations in the Escalante River was done to explore the potential of using surface waters to determine an average ground-water age for the drainage basin (table 6). Whereas tritium values indicate a before- or after-1950 recharge time, CFCs provide a discrete age (for example 22-year-old water, plus or minus some uncertainty). Average groundwater age is a fundamental characteristic of a groundwater system. Recharge rates and the amount of water stored in the ground-water reservoir are both reflected in the average ground-water age; increased recharge rates will decrease age, increased storage will increase age (Cook and Böhlke, 2000, p. 9). If ground-water age were preserved in the perennial streamflow, then surface-water samples might be useful to estimate flow-weighted mean transit times. Unlike tritium, CFCs are dissolved gases that exchange rapidly with the atmosphere. To interpret CFC ages, the gasexchange rate of the Escalante River must be known. That is beyond the scope of this report; therefore, only CFC concentrations are presented in table 6. Further research is needed to determine the utility of CFCs to quantify average ground-water travel times in the Escalante River drainage basin.

\section{Comparison of 1981 and 2001 Seepage Investigations}

Seepage along the Escalante River also was measured during October 1981; the data are listed in table 3 and described by Blanchard (1986, p.19). The 1981 and 2001 measurements for each individual reach of the Escalante River from the USGS gage (site 10) to Boulder Creek (site 29) are graphed in figure 2. Flows were greater in 1981 for all reaches because 1981 was hydrologically and climatically wetter than 2001.

The average October streamflow at the Escalante gage (09337500, site 10) for 47 years of record (1943$55,1973-2002)$ is $7.70 \mathrm{ft}^{3} / \mathrm{s}$. In October 1981, the average streamflow was $14.2 \mathrm{ft}^{3} / \mathrm{s}$ and represents the seventh highest for the period of record. By contrast, the average streamflow in October 2001 was $3.15 \mathrm{ft}^{3} / \mathrm{s}$ and represents the eleventh lowest. Tributary flows at Mamie Creek (site 12), Sand Creek (site 14), and Calf Creek (site 18) were of similar magnitudes for both time periods. Flow in Boulder Creek was about 50 percent greater in October 1981 than in October 2001.

To compare measurements in 1981 and 2001, climatic conditions preceding the two periods were examined using long-term precipitation records for the town of Escalante. Precipitation has been recorded at Escalante since 1901 (Western Regional Climate Center, 2004). The cumulative departure of total precipitation from normal for July to October 1981 was +3.61 inches. Departure for the same period in 2001 was -1.68 inches. Cumulative departure for the 5 years prior to October 1981 and October 2001 were, respectively, +5.71 inches and -1.41 inches (Western 


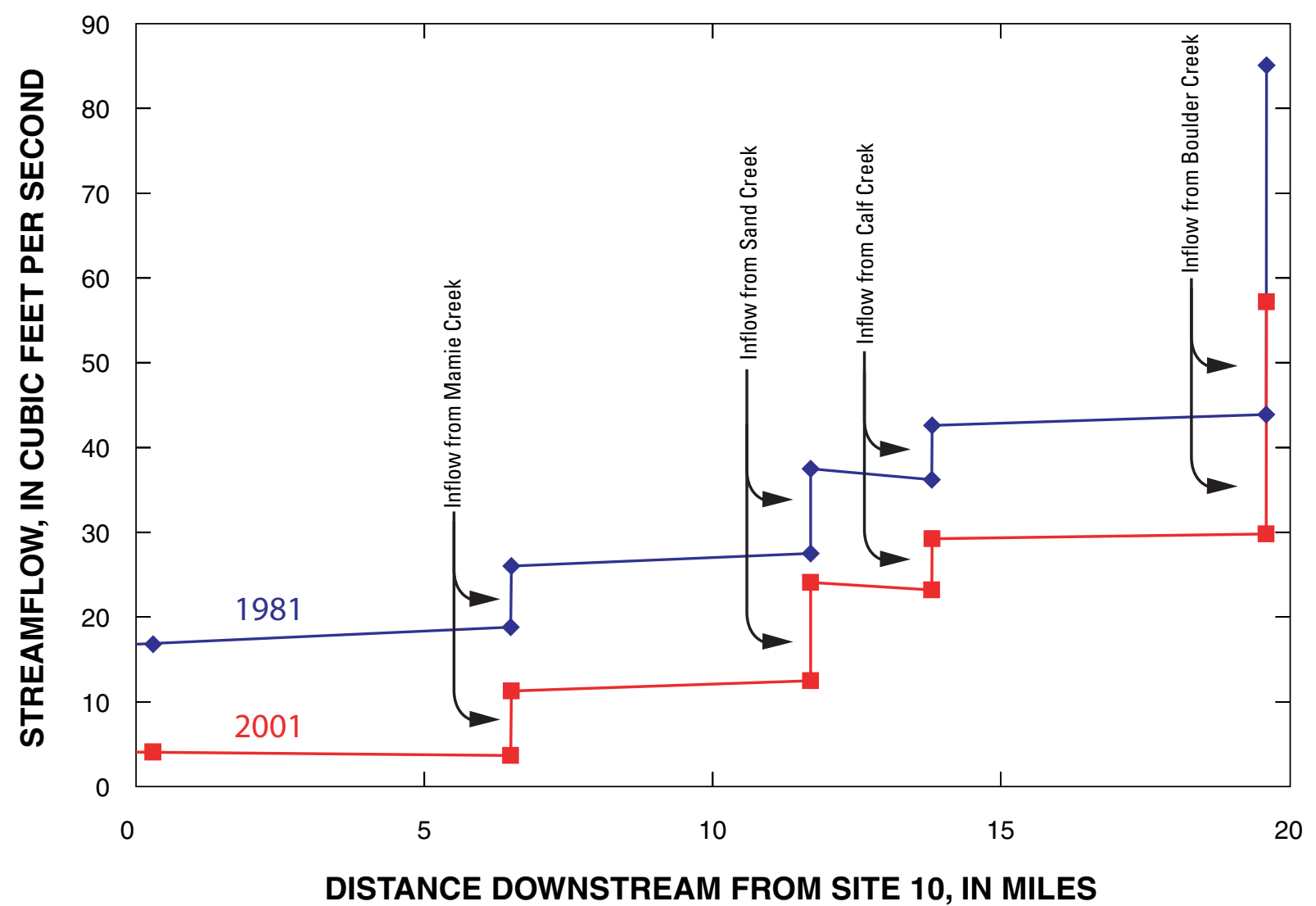

Figure 2. Streamflow on October 21, 1981, and October 23, 2001, along the Escalante River, Garfield and Kane Counties, Utah.

Regional Climate Center, 2004). These comparisons indicate that conditions preceding the 1981 seepage investigation were wetter than conditions preceding 2001. Cumulative departure is the sum of difference between each month or year's measured precipitation and the long-term average, and describes the collective affects of climatic trends. The table below summarizes the departures.

Departure from long-term average precipitation at Escalante, Utah

\begin{tabular}{lc}
\hline \multicolumn{1}{c}{ Time period } & $\begin{array}{c}\text { Amount above } \\
\text { (+) or below (-) } \\
\text { average }\end{array}$ \\
\hline Cumulative departure for July-October, 1981 & +3.61 inches \\
Cumulative departure for 1977-81 (previous 5 years) & +5.71 inches \\
Cumulative departure for July-October, 2001 & -1.68 inches \\
Cumulative departure for 1997-2001 (previous 5 years) & -1.41 inches \\
\hline
\end{tabular}

Perennial or base flow in Mamie, Sand, and Calf Creeks appears only slightly affected by changes in precipitation prior to October 1981 and October 2001. However, flow in Boulder Creek seems to have been affected by the less-than-normal precipitation prior to October 2001. Perennial or base flow in Mamie, Sand, and Calf Creeks originates mainly as ground-water discharge from the Navajo aquifer. A component of perennial flow in Boulder Creek is also derived from the Navajo aquifer. A partial explanation for the variation in perennial flow measured at the mouth of Boulder Creek is that the additional flow measured in 1981 , is derived from shallow circulating ground water. This might include ground water stored in soils, and adjacent stream-channel and alluvial deposits.

Streamflow derived from ground water will show a significant change only if recharge to, and water 
levels in, the underlying aquifer/aquifers change. By inference, it appears that any decrease in recharge to the Navajo aquifer (which underlies Mamie, Sand, and Calf Creeks) caused by the drier period had little effect on water levels. Probably the amount of water stored in the Navajo aquifer is significantly larger than any potential 5-year variations in recharge. Alternatively, there does appear to be a ground-water component in the Boulder Creek drainage that is affected by 5 -year changes in climate and recharge.

\section{HYDROLOGIC AND WATER-QUALITY DATA}

As a resource to future hydrologic investigations of the Escalante River drainage basin, a compilation of all hydrologic and water-quality data collected by the USGS for the area is published as a series of tables located at the end of this report. The sources of these data are listed in table 1 and discussed in the "Previous Studies" section of this report. The compilation consists of data for 64 surface-water sites and 28 springs (pl. 1). Data published here were collected by the USGS in the Escalante River drainage basin from September 1909 for the Escalante River near Escalante gage (09337500) to December 2002 for a specificconductance measurement of surface water at Boulder Creek near Boulder Creek gaging station (09339000) when it was reactivated.

Discharge data were collected for different periods of time at 12 gaging stations operated and maintained by the USGS in the Escalante River drainage basin beginning in 1909 at the Escalante River near Escalante gage (09337500), which was called Escalante Creek until 1913. Selected data for gaging stations in the Escalante River drainage basin are presented in table 7 and include period of record, drainage area, annual mean discharge for complete water years, extreme maximum and minimum discharge quantities, and dates.

Field measurements of specific conductance and temperature taken during routine site visits to the gages at Pine Creek near Escalante (gaging station 09337000) during 1969-91, and Escalante River near Escalante (gaging station 09337500) during 1971-91, are listed in tables 8 and 9, respectively. These data are presented to show near-monthly and seasonal variation.
Physical properties and results of chemical analyses for water collected at the gaging station at Escalante River near Escalante (09337500) are listed in table 10. The data were collected during 1969-72 and are presented here as background water-quality information.

Physical properties and results of chemical analyses for water collected at the gaging station at Escalante River at mouth (09339500) during 1951-53 are listed in table 11 and are presented for historical purposes only. The gage was discontinued in September 1953 and the site was covered by the rising waters of Lake Powell in June of 1963. This gage was established to determine streamflow, sediment loads, and chemical constituents and required a USGS employee to live at the site. Access to the gage was so obscure over the stretches of slickrock that paint markings were applied on the rock to keep travelers to the gage on course. Later, in an article about the Escalante area, W.R. Moore (1955, p. 414) quoted a local horse packer who stated "The Government built the cheapest highway in history. Seven miles with a gallon of paint."

Water-quality analyses for common constituents in water from selected sites in the Escalante River drainage basin are presented in table 12. Samples were collected from 14 surface-water sites and 18 spring sites from April 1981 to August 2002.

\section{SUMMARY}

This report contains the results of the October 2001 seepage investigation along the Escalante River and includes a compilation of hydrologic and waterquality data collected by the USGS within the Escalante River drainage basin from 1909 to 2002 for 64 surface-water sites and 28 springs (pl. 1). This report was written as part of a larger cooperative study by the USGS and BLM done to identify and understand the hydrologic system within Grand StaircaseEscalante National Monument. The purpose of the seepage investigation was to determine if large amounts of surface water in the Escalante River were lost or gained, to determine where those losses or gains occurred, to quantify the losses or gains and determine if they were significant, and to identify which rock formations were involved. 
None of the 15 reaches along the Escalante River between the Escalante gage and Stevens Canyon where discharge was measured during the seepage investigation of October 23 and 24, 2001, had computed losses or gains that exceeded the normalized percentage error. Losses or gains were computed for each reach by subtracting the sum of the discharge measured at an upstream site and any tributary inflow in that reach from the discharge measured at a downstream site. For ease of comparison among reaches, the computed losses or gains were normalized. A computed loss or gain is considered significant when the normalized difference is greater than the normalized error.

Individual reaches along tributaries in the upper canyons could be the focus of future seepage investigations. Specifically, tributaries such as Boulder Creek, Mamie Creek, Sand Creek, Deer Creek, and Calf Creek offer the most potential to find reaches of significant gains in surface-water discharge.

\section{REFERENCES CITED}

Blanchard, P.J., 1986, Ground-water conditions in the Kaiparowits Plateau area, Utah and Arizona, with emphasis on the Navajo Sandstone: Utah Department of Natural Resources Technical Publication No. 81, 87 p.

Butler, Elmer, and Marsell, R.E., 1972, Cloudburst floods in Utah, 1939-69: Utah Department of Natural Resources, Division of Water Resources, Cooperative Investigations Report No. 11, 103 p.

Christiansen, R.C., Johnson, E.B., and Plantz, G.L., 1986, Manual for estimating selected streamflow characteristics of natural-flow streams in the Colorado River basin in Utah: U.S. Geological Survey WaterResources Investigations Report 85-4297, 39 p.

Cook, P.G., and Böhlke, J.K., 2000, Determining timescales for groundwater flow and solute transport, in Cook, P.G. and Herczeg, A.L., eds., Environmental Tracers in Subsurface Hydrology: Boston, Kluwer Academic Publishers, p. 1-30.

Cooley, M.E., 1965, Stratigraphic sections and records of springs in the Glen Canyon region of Utah and Arizona: Museum of Northern Arizona Technical Series No. 6, 140 p. [Part of the Upper Colorado River Basin Salvage Program between National Park Service and Museum of Northern Arizona, Memorandum of Agreement 1410-0333-666.]
Doelling, H.H., Blackett, R.E., Hamblin, A.H., Powell, J.D., and Pollock, G.L., 2000, Geology of Grand StaircaseEscalante National Monument, Utah: Utah Geological Association Publicaton 28, p. 189-231.

Freethey, G.W., and Cordy, G.E., 1991, Geohydrology of Mesozoic rocks in the upper Colorado River basin in Arizona, Colorado, New Mexico, Utah, and Wyoming, excluding the San Juan Basin: U.S. Geological Survey Professional Paper 1411-C, 118 p.

Goode, H.D., 1969, Reconnaissance appraisal of the water resources near Escalante, Garfield County, Utah: Utah Geological and Mineralogical Survey Water-Resources Bulletin 11, 38 p.

Gregory, H.I., and Moore, R.G., 1931, The Kaiparowits region: U.S. Geological Survey Professional Paper 164, $161 \mathrm{p}$.

Hackman, R.J., and Wyant, D.G., 1973, Geology, structure, and uranium deposits of the Escalante quadrangle, Utah and Arizona: U.S. Geological Survey Miscellaneous Investigations Series Map I-744, 2 sheets, scale 1:250,000.

Herbert, L.R., and others, 1997, Water resources data, Utah, water year 1996: U.S. Geological Survey Water-Data Report UT- 96-1, 300 p.

Herbert, L.R., and others, 1998, Water resources data, Utah, water year 1997: U.S. Geological Survey Water-Data Report UT-97-1, 288 p.

Herbert, L.R., and others, 1999, Water resources data, Utah, water year 1998: U.S. Geological Survey Water-Data Report UT-98-1, 290 p.

Herbert, L.R., and others, 2000, Water resources data, Utah, water year 1999: U.S. Geological Survey Water-Data Report UT-99-1, 340 p.

Herbert, L.R., and others, 2001, Water resources data, Utah, water year 2000: U.S. Geological Survey Water-Data Report UT-00-1, 380 p.

Herbert, L.R., and others, 2002, Water resources data, Utah, water year 2001: U.S. Geological Survey Water-Data Report UT-01-1, 440 p.

Hunt, C.B., 1974, Natural regions of the United States and Canada: San Francisco, W.H. Freeman and Company, $725 \mathrm{p}$.

Moore, W.R., 1955, Escalante: Utah's river of arches: National Geographic Magazine no. 108 (September 1955), p. 399-425.

Plantz, G.G., 1983, Selected hydrologic data, Kolob-AltonKaiparowits coal-fields area, south-central Utah: U.S. Geological Survey Open-File Report 83-871, 25 p.

Plantz, G.G., 1985, Hydrologic reconnaissance of the Kolob, Alton, and Kaiparowits Plateau coal fields, southcentral Utah: U.S. Geological Survey Hydrologic Investigation Atlas HA-684, 2 sheets, scale 1:250,000. 
Price, Don, 1978, Map showing principal drainage basins, principal runoff-producing areas, and selected streamflow data in the Kaiparowits coal-basin area, Utah: U.S. Geological Survey Miscellaneous Investigations Map I-1033-E, scale 1:125,000.

Price, Don, 1979, Map showing general chemical quality of surface water in the Kaiparowits coal-basin area: U.S. Geological Survey Miscellaneous Investigations Map I1033-F, scale 1:125,000.

Rantz, S.E., and others, 1982, Measurement and computation of streamflow: Volume 1, Measurement of stage and discharge; Volume 2, Computation of discharge: U.S. Geological Survey Water-Supply Paper 2175 , v. 1, p. 1-284, v. 2, 285-631.

ReMillard, M.E., and others, 1983, Water resources data, Utah, water years 1982: U.S. Geological Survey WaterData Report UT-82-1, 497 p.

ReMillard, M.E., and others, 1984, Water resources data, Utah, water year 1983: U.S. Geological Survey WaterData Report UT-83-1, 489 p.

ReMillard, M.E., and others, 1985, Water resources data, Utah, water year 1984: U.S. Geological Survey WaterData Report UT-84-1, 463 p.

ReMillard, M.E., and others, 1986, Water resources data, Utah, water year 1985: U.S. Geological Survey WaterData Report UT-85-1, 400 p.

ReMillard, M.E., and others, 1987, Water resources data, Utah, water year 1986: U.S. Geological Survey WaterData Report UT-86-1, 404 p.

ReMillard, M.E., and others, 1988, Water resources data, Utah, water year 1987: U.S. Geological Survey WaterData Report UT-87-1, 367 p.

ReMillard, M.E., and others, 1989, Water resources data, Utah, water year 1988: U.S. Geological Survey WaterData Report UT-88-1, 364 p.

ReMillard, M.E., and others, 1990, Water resources data, Utah, water year 1989: U.S. Geological Survey WaterData Report UT-89-1, 383 p.

ReMillard, M.E., and others, 1991, Water resources data, Utah, water year 1990: U.S. Geological Survey WaterData Report UT-90-1, 383 p.

ReMillard, M.E., and others, 1992, Water resources data, Utah, water year 1991: U.S. Geological Survey WaterData Report UT-91-1, 375 p.

ReMillard, M.E., and others, 1993, Water resources data, Utah, water year 1992: U.S. Geological Survey WaterData Report UT-92-1, 343 p.

ReMillard, M.E., and others, 1994, Water resources data, Utah, water year 1993: U.S. Geological Survey WaterData Report UT-93-1, 333 p.

ReMillard, M.E., and others, 1995, Water resources data, Utah, water year 1994: U.S. Geological Survey WaterData Report UT-94-1, 329 p.
ReMillard, M.E., and others, 1996, Water resources data, Utah, water year 1995: U.S. Geological Survey WaterData Report UT-95-1, 313 p.

Thomas, B.E., Hjalmarson, H.W., and Waltemeyer, S.D., 1997, Methods for estimating magnitude and frequency of floods in the southwestern United States: U.S. Geological Survey Water-Supply Paper 2433, 195 p.

Thomas, B.E., and Lindskov, K.L., 1983, Methods for estimating peak discharge and flood boundaries of streams in Utah: U.S. Geological Survey WaterResources Investigations Report 83-4129, 77 p.

U.S. Department of Energy, Nevada Operations Office, 2000, United States nuclear test, July 1945 through September 1992: DOE/NV-209, rev 15, December 2000, 185 p. Available electronically at http://www.nv.doe.gov/news\&pubs/publications/history reports/pdfs/DOENV209_REV15.pdf

U.S. Geological Survey, 1954, Compilation of records of surface waters of the United States through September 1950, Part 9. Colorado River basin: U.S. Geological Survey Water-Supply Paper 1313, 749 p.

U.S. Geological Survey, 1964, Compilation of records of surface waters of the United States, October 1950 to September 1960, Part 9. Colorado River basin: U.S. Geological Survey Water-Supply Paper 1733, 586 p.

U.S. Geological Survey, 1970, Surface water supply of the United States 1961-65, Part 9. Volume 2: U.S. Geological Survey Water-Supply Paper 1925, 618 p.

U.S. Geological Survey, 1973, Surface water supply of the United States 1961-65, Part 9. Volume 2: U.S. Geological Survey Water-Supply Paper 2125, 634 p.

U.S. Geological Survey, 1962, Surface water records of Utah, water year 1961, $272 \mathrm{p}$.

U.S. Geological Survey, 1963, Surface water records of Utah, water year 1962, $270 \mathrm{p}$.

U.S. Geological Survey, 1964, Surface water records of Utah, water year 1963, $272 \mathrm{p}$.

U.S. Geological Survey, 1965, Surface water records of Utah, water year 1964, 283 p.

U.S. Geological Survey, 1966, Water resources data for Utah, water year 1965 part 1: Surface water records, $315 \mathrm{p}$.

U.S. Geological Survey, 1967, Water resources data for Utah, water year 1966 part 1: Surface water records, $336 \mathrm{p}$.

U.S. Geological Survey, 1968, Water resources data for Utah, water year 1967 part 1: Surface water records, $339 \mathrm{p}$.

U.S. Geological Survey, 1969, Water resources data for Utah, water year 1968 part 1: Surface water records, $336 \mathrm{p}$.

U.S. Geological Survey, 1970, Water resources data for Utah, water year 1969 part 1: Surface water records, $301 \mathrm{p}$. 
U.S. Geological Survey, 1971, Water resources data for Utah, water year 1970 part 1: Surface water records, $297 \mathrm{p}$.

U.S. Geological Survey, 1972, Water resources data for Utah, water year 1971 part 1: Surface water records, $291 \mathrm{p}$.

U.S. Geological Survey, 1973, Water resources data for Utah, water year 1972 part 1: Surface water records, $311 \mathrm{p}$.

U.S. Geological Survey, 1974, Water resources data for Utah, water year 1973 part 1: Surface water records, $303 \mathrm{p}$.

U.S. Geological Survey, 1975, Water resources data for Utah, water year 1974 part 1: Surface water records, $299 \mathrm{p}$.

U.S. Geological Survey, 1976, Water resources data, Utah, water year 1975: U.S. Geological Survey Water-Data Report UT-75-1, p. 509.

U.S. Geological Survey, 1977, Water resources data, Utah, water year 1976: U.S. Geological Survey Water-Data Report UT-76-1, 617 p.

U.S. Geological Survey, 1978, Water resources data, Utah, water year 1977: U.S. Geological Survey Water-Data Report UT-77-1, 548 p.

U.S. Geological Survey, 1979, Water resources data, Utah, water year 1978: U.S. Geological Survey Water-Data Report UT-78-1, 492 p.

U.S. Geological Survey, 1980, Water resources data, Utah, water year 1979: U.S. Geological Survey Water-Data Report UT-79-1, 604 p.

U.S. Geological Survey, 1981, Water resources data, Utah, water year 1980: U.S. Geological Survey Water-Data Report UT-80-1, 684 p.

U.S. Geological Survey, 1982, Water resources data, Utah, water year 1981: U.S. Geological Survey Water-Data Report UT-81-1, 708 p.

Western Regional Climate Center, 2004, Escalante, Utah, monthly total precipitation, accessed during January 2004, at URL http://www.wrcc.dri.edu/cgibin/cliMAIN.pl?utesca

Whitaker, G.L., 1969, Summary of maximum discharges in Utah streams: Utah Department of Natural Resources, Technical Publication No. 21, 42 p.

Wilberg, D.E., 1995, Origin of water that discharges from Calf Creek Spring, Garfield County, Utah: U.S. Geological Survey Open-File Report 95-340, 10 p.

Wilberg, D.E., Swenson, R.L., Slaugh, B.A., Howells, J.H., and Christiansen, H.K., 2001, Seepage investigation for Leap, South Ash, Wet Sandy, and Leeds Creek in the Pine Valley Mountains, Washington County, Utah, 1998: U.S. Geological Survey Water-Resources Investigations Report 01-4237, 42 p.
Wilberg, D.E., and others, 2003, Water resources data, Utah, water year 2002: U.S. Geological Survey Water-Data Report UT-02-1, $391 \mathrm{p}$.

Woolley, R.R., 1946, Cloudburst floods in Utah, 1850-1938: U.S. Geological Survey Water-Supply Paper 994, $128 \mathrm{p}$. 
Table 1. Records of selected surface-water sites and springs in the Escalante River drainage basin, Garfield and Kane Counties, Utah

[Site number: See plate 1 for site location. Local number: See numbering system used for hydrologic-data sites in Utah, unsurveyed indicates that individual section boundaries were not available for the location and the local number was based on extrapolation from nearby sections; Description of site: Number in parentheses is gaging station number; Site ID: A unique number in the USGS database that is used to identify a site and is based on the latitude (first 6 digits) and longitude (last 7 digits) of the site; Source of data: USGS, U.S. Geological Survey; WSP, USGS Water-Supply Paper; OFR, USGS Open-File Report; TP, Technical Publication of the Utah Department of Natural Resources; WDR, USGS Water-Data Report; Do., ditto; BLM, Bureau of Land Management; ft, feet; mi, mile]

\begin{tabular}{|c|c|c|c|c|c|}
\hline $\begin{array}{c}\text { Site } \\
\text { number }\end{array}$ & Local number & Description of site & Site ID & $\begin{array}{c}\text { Table } \\
\text { containing } \\
\text { additional } \\
\text { data }\end{array}$ & Source of data \\
\hline
\end{tabular}

\begin{tabular}{|c|c|c|c|c|c|}
\hline \multirow[b]{2}{*}{1} & \multicolumn{5}{|c|}{ SURFACE-WATER SITES } \\
\hline & (D-35-2)16aca-1 & $\begin{array}{l}\text { North Creek near Escalante (09335500) } 0.1 \mathrm{mi} \\
\text { above mouth }\end{array}$ & 3746001114059 & 7 & WSP 1733 , p. 363 \\
\hline 2 & (D-34-1)31aba-1 & $\begin{array}{l}\text { Birch Creek about } 10.5 \text { mi above confluence } \\
\text { with North Creek }\end{array}$ & 3748501114942 & 12 & Site 21 in OFR $83-871$ \\
\hline 3 & (D-35-1)13dba-1 & Birch Creek near Escalante (09336000) & 3745441114415 & 7 & \\
\hline 4 & (D-36-1)9cbc-1 & Upper Valley Creek near Liston Flat & 3741171114804 & 12 & Site 25 in OFR 83-871 \\
\hline 5 & (D-35-2)29bba-1 & Upper Valley Creek near Escalante (09336400) & 3744301114235 & 7 & TP 21, p. 33 \\
\hline 6 & (D-35-2)16cbb-1 & $\begin{array}{l}\text { Birch Creek } 0.8 \text { mi above confluence with } \\
\text { North Creek }\end{array}$ & 3745481114139 & 12 & Site 23 in OFR $83-871$ \\
\hline 7 & (D-35-2)16aca-1 & Birch Creek at mouth (09336500) & 3745541114102 & 7 & WSP 1733 , p. 364 \\
\hline 8 & (D-35-2)16adb-1 & $\begin{array}{l}\text { Escalante River } 400 \mathrm{ft} \text { below confluence of } \\
\text { North and Birch Creeks }\end{array}$ & 3745561114051 & 12 & Site 22 in OFR $83-871$ \\
\hline 9 & $(\mathrm{D}-34-2) 12 \mathrm{cac}-1$ & Pine Creek near Escalante (09337000) & 3751451113807 & 7,8 & WDR UT-01-1 \\
\hline 10 & (D-35-3)9dba-1 & $\begin{array}{l}\text { Escalante River near Escalante at USGS gage } \\
\quad(09337500)\end{array}$ & 3746411113426 & $2,3,4,7,9,10$ & Do. \\
\hline 11 & (D-35-4)7bdd-1 & Escalante River above Mamie Creek & 3746501113019 & $2,3,4,12$ & TP 81 \\
\hline 12 & (D-35-4)7bda-1 & Mamie Creek at mouth & 3746561113020 & $2,3,4$ & \\
\hline 13 & (D-35-4)10ccb-1 & Escalante River above Sand Creek & 3746301112726 & $2,3,4$ & TP 81 \\
\hline 14 & (D-35-4)10ccb-2 & Sand Creek at mouth & 3746301112725 & $2,3,4$ & Do. \\
\hline 15 & $(\mathrm{D}-35-4) 12 \mathrm{cac}-1$ & Escalante River above Calf Creek & 3746321112504 & $2,3,4$ & Do. \\
\hline 16 & (D-35-4)11abd-1 & $\begin{array}{l}\text { Calf Creek above BLM campground, near } \\
\text { Escalante }\end{array}$ & 3747481112445 & $4,8,12$ & OFR 95-340 \\
\hline 17 & (D-35-4)1 acc-1 & Calf Creek at BLM campground bridge & 3747331112452 & 3,4 & OFR 95-340 \\
\hline 18 & (D-35-4)12cac-2 & Calf Creek at mouth & 3746361112506 & $2,3,4$ & TP 81 \\
\hline 19 & (D-35-4)12cad-1 & $\begin{array}{l}\text { Escalante River below Calf Creek at USGS } \\
\text { temporary gage }\end{array}$ & 3746351112456 & $2,3,4,6,12$ & \\
\hline 20 & (D-35-5)22bbb-1 & Escalante River above Boulder Creek & 3745251112058 & $2,3,4,8,12$ & TP 81 \\
\hline 21 & (D-32-4)10aca-1 & $\begin{array}{l}\text { East Fork Boulder Creek near Boulder } \\
\quad(09338000)\end{array}$ & 3802301112700 & 4,7 & WSP 1733 , p. 367 \\
\hline 22 & (D-32-5)29 (unsurveyed) & East Fork Deer Creek near Boulder (09338500) & 3800051112320 & 7 & WSP 1733 , p. 368 \\
\hline 23 & $(\mathrm{D}-34-5) 16 \mathrm{aca}-1$ & Deer Creek near Boulder (09338900) & 3751121112116 & 4,7 & TP 21, p. 33 \\
\hline 24 & (D-35 -5)9bda-1 & Boulder Creek near Boulder (09339000) & 3746551112134 & 4,7 & \\
\hline 25 & (D-35-5)22bbb-2 & Boulder Creek at mouth & 3745261112058 & $2,3,4,6,12$ & \\
\hline 26 & (D-35-5) $15 \mathrm{dcd}-1$ & $\begin{array}{l}\text { Unnamed tributary 1.1-mi below Boulder } \\
\text { Creek, left bank }\end{array}$ & 3745271112013 & 4 & \\
\hline 27 & (D-35-5)35aad-1 & $\begin{array}{l}\text { Unnamed tributary } 1.6 \mathrm{mi} \text { above The Gulch and } \\
0.1 \mathrm{mi} \text { above mouth }\end{array}$ & 3743331111850 & 4 & \\
\hline 28 & (D-35-5)36adc-1 & $\begin{array}{l}\text { Pool } 200 \mathrm{ft} \text { up unnamed tributary } 0.3 \mathrm{mi} \text { above } \\
\text { The Gulch }\end{array}$ & 3743211111800 & 4 & \\
\hline 29 & (D-35-6)36aad-1 & Escalante River above The Gulch & 3743311111748 & $2,3,4$ & \\
\hline 30 & (D-35-6)36aad-2 & The Gulch at mouth & 3743321111748 & $2,3,4$ & \\
\hline 31 & (D-35-6)31bbd-1 & Escalante River below The Gulch & 3743291111732 & 3 & TP 81 \\
\hline 32 & (D-35-6)32dbc-1 & Escalante River above Horse Canyon & 3743071111600 & $2,3,4$ & \\
\hline 33 & (D-35-6)32dbd-1 & Horse Canyon $500 \mathrm{ft}$ above mouth & 3743091111555 & 4 & \\
\hline 34 & (D-36-6)23aac-1 & Silver Falls Creek at mouth & 3740011111241 & 3,4 & \\
\hline 35 & (D-35-2)36dcd-1 & Alvey Wash $500 \mathrm{ft}$ above Coal Bed Canyon & 3742521113743 & 12 & Site 24 in OFR $83-871$ \\
\hline 36 & (D-36-6)23dbb-1 & Escalante River above Harris Wash & 3739461111254 & $2,3,4,6$ & \\
\hline 37 & (D-36-6)23acc-1 & Harris Wash at mouth & 3739481111255 & $2,3,4$ & \\
\hline
\end{tabular}


Table 1. Records of selected surface-water sites and springs in the Escalante River drainage basin, Garfield and Kane Counties, Utah—Continued

\begin{tabular}{cccc}
\hline $\begin{array}{c}\text { Site } \\
\text { number }\end{array}$ & Local number & Description of site & Table \\
containing ID & $\begin{array}{c}\text { Source of data } \\
\text { dational } \\
\text { data }\end{array}$ \\
\hline
\end{tabular}

\section{SURFACE-WATER SITES-Continued}

38 (D-36-7)31dcc-1

39 (D-37-7)6ded-1 (unsurveyed)

40 (D-37-7)7aba-1 (unsurveyed)

41 (D-37-7)8baa-1 (unsurveyed)

42 (D-38-4)10dad-1

43 (D-37-5)29bca

44 (D-37-7)22bda-1

45 (D-37-7)22bda-2

46 (D-37-7)25aac-1

47 (D-37-7)25acc-2

48 (D-37-7)25dad-1

49 (D-38-8)5ccb-1

50 (D-38-8) $5 \mathrm{ccc}-1$

51 (D-38-8)5ccb-2

52 (D-38-8)4bcd-1

53 (D-38-8)4cca-1

54 (D-38-8)22 (unsurveyed)

55 (D-38-8)23 (unsurveyed)

56 (D-38-8)35 (unsurveyed)

57 (D-38-8)35 (unsurveyed)

58 (D-38-8)35 (unsurveyed)

59 (D-39-8)1adb-1 (unsurveyed)

60 (D-39-8)12add-1 (unsurveyed)

61 (D-39-9)7bcd-1

62 (D-39-8)12add-2 (unsurveyed)

63 (D-39-8)12ddd-1

64 (D-40-9)23cb (unsurveyed)
Unnamed left bank tributary 1.2 mi above Fence 3737381111050 Canyon

Escalante River above Fence Canyon

Fence Canyon at mouth

Neon Canyon at base of falls $0.6 \mathrm{mi}$ above mouth

Left Hand Collett Canyon

Twentymile Wash near Escalante (09339200)

Escalante River above Twentyfive Mile Wash

Twentyfive Mile Wash at mouth

Moody Creek

Escalante River below Moody Creek

East Moody Canyon at mouth

Escalante River above Scorpion Gulch

Scorpion Gulch near mouth

Scorpion Gulch at mouth

$3736461111042 \quad 2,3,4,6,12$

$3736451111042 \quad 2,3,4$

$3736421110950 \quad 4$

$3731081112708 \quad 12$

$3733521112315 \quad 7$

$3734461110742 \quad 2,3,4,6$

$3734461110744 \quad 2,3,4,6$

$3733581110509 \quad 3$

$3733561110509 \quad 2,3,4,6$

$3733301110458 \quad 4$

$3731441110344 \quad 2,3,4,6$

$3731381110345 \quad 5,6,12$

$3731441110343 \quad 2,3,4$

Unnamed tributary 2 mi below Scorpion Gulch $3732041110232 \quad$ 4, 5, 6 and $0.4 \mathrm{mi}$ from mouth (informally designated tuning fork canyon)

Mouth of unnamed tributary 2 mi below

3731451110239

2,3

Scorpion Gulch on left (informally

designated tuning fork canyon)

Mouth of unnamed canyon 6.5 mi above Fools 3729531110201 Canyon on left bank

Escalante River 3.7 mi above Fools Canyon

Escalante River above Fools Canyon

Fools Canyon 1 mi above mouth

2929111110007

3728021110004

3727571110046

3728021110005

Fools Canyon at mouth

3727071105854 on left bank

Escalante River above Stevens Canyon

3726101105852

Stevens Canyon near mouth

3726081105838

Stevens Canyon at mouth

3726081105852

Escalante River at Coyote Gulch

3725411105847

Escalante River at mouth near Escalante, $2.2 \mathrm{mi} 3718591105411$ below Davis Gulch and 5.1 mi above

confluence with Colorado River left bank

(09339500)

\section{SPRINGS}

Spring in headwaters of Birch Creek about $2.5 \quad 3749441115125$ mi south of Griffin Top

Spring area in Corn Creek about 2 mi northeast 3746511115023 of Barney Top

Spring near Yankee Meadow about 1 mi east of 3744451115055 Table Cliff Plateau

Garden Spring near Upper Valley guard station 3742081115029

Spring in Upper Valley above Allen Creek 3742581114704

Spring in Upper Valley Creek above confluence 3745541114057 with North Creek

Spring in Mamie Creek $400 \mathrm{ft}$ above mouth $3746571113021 \quad 3,4$
TP 21, p. 33

4

$2,3,4$

$2,3,4,6$

4,5

$2,3,4$

4

$2,3,4,6$

5,12

3,4

4

4, 7, $11 \quad$ WSP 1733, p. 369

12

OFR 83-871

Do.

Do.

Do.

Do.

Do.

see Goode (1969) for data from other springs in Death Hollow 
Table 1. Records of selected surface-water sites and springs in the Escalante River drainage basin, Garfield and Kane Counties, Utah—Continued

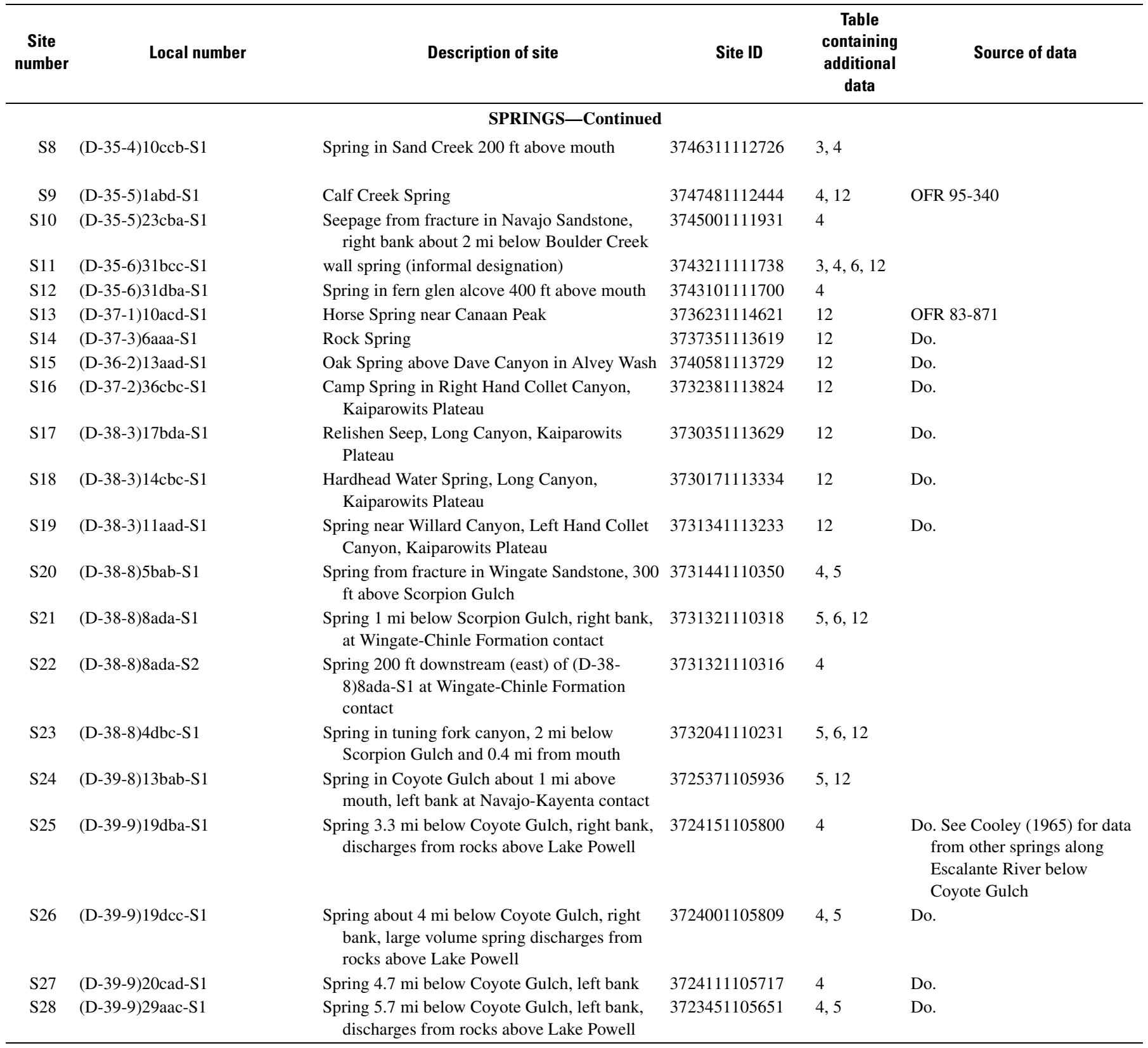


Table 2. Error analysis for data collected during seepage investigation along 15 reaches of the Escalante River between gaging station 09337500 and Stevens Canyon, Garfield and Kane Counties, Utah, October 2001

[Site number: See table 1 and plate 1 for location of sites and reaches; Description of reach: Tributary inflows with measured or estimated discharge are described and numbered; $\mathbf{Q}_{\mathbf{u s}}$, discharge measured at upstream site; $\mathbf{Q}_{\mathbf{d s}}$, discharge measured at downstream site; $\mathbf{Q}_{\text {in }}$, discharge measured at tributary inflow. If tributary is not mentioned, then it had zero discharge; $\mathrm{ft}^{3} / \mathrm{s}$, cubic feet per second; e, estimated; $\mathrm{G}$, in the opinion of the hydrographer, the measured discharge is within 5 percent of actual discharge; F, within 8 percent; $P$, greater than 8 percent; Computation of loss (-) or gain $=Q_{d s}-\left(Q_{u s}+Q_{i n}-Q_{d i v e r s i o n}\right)$; $\mathbf{N}_{\mathbf{d}} \%$, Normalized percentage difference, used to determine the difference between discharge measured at upstream and downstream cross sections of a given channel reach. See text for equations and definitions of terms; $\mathbf{N}_{\mathbf{e}} \%$, Normalized percentage error, used to determine if a computed loss or gain significantly exceeds errors associated with discharge measurement. See text for equations and definitions of terms; $\mathbf{N}_{\mathbf{d}} \%$, greater than (>) Ne\%: $\mathbf{Y}$, Yes; $\mathbf{N}$, No. If Y, then computed loss (-) or gain is considered significant. Formation: Jn, Jurassic Navajo Sandstone; Jk, Jurassic Kayenta Formation; Jw, Jurassic Wingate Sandstone; Trc, Triassic Chinle Formation; - , no data available]

\begin{tabular}{|c|c|c|c|c|c|c|c|c|c|}
\hline $\begin{array}{c}\text { Site } \\
\text { number }\end{array}$ & Description of reach & $\mathbf{0}_{\mathbf{u s}}\left(\mathbf{f t}^{3} / \mathbf{s}\right)$ & $\mathbf{0}_{\mathrm{ds}}\left(\mathbf{f t} \mathbf{t}^{3} / \mathbf{s}\right)$ & $0_{\text {in }}\left(\mathrm{ft}^{3} / \mathbf{s}\right)$ & $\begin{array}{l}\text { Compu- } \\
\text { tation } \\
\text { of loss (-) } \\
\text { or gain }\end{array}$ & $\begin{array}{c}\text { Normalized } \\
\text { percentage } \\
\text { difference } \\
\left(\mathbf{N}_{\mathbf{d}} \%\right)\end{array}$ & $\begin{array}{l}\text { Normalized } \\
\text { percentage } \\
\text { error } \\
\left(\mathrm{N}_{\mathrm{e}} \%\right)\end{array}$ & $\begin{array}{l}\mathbf{N}_{\mathrm{d}} \%> \\
\mathbf{N}_{\mathrm{e}} \% \\
(\mathbf{Y} \text { or } \mathbf{N})\end{array}$ & Formation \\
\hline \multicolumn{10}{|c|}{ October 23, 2001} \\
\hline 10 to 11 & $\begin{array}{l}\text { Escalante River at USGS gage (09337500) to } \\
\text { Escalante River above Mamie Creek }\end{array}$ & $4.07 \mathrm{G}$ & $3.66 \mathrm{P}$ & 0 & -0.41 & -10.1 & -12.2 & $\mathrm{~N}$ & $\mathrm{Jn}$ \\
\hline 11 to 13 & $\begin{array}{l}\text { Escalante River above Mamie Creek to } \\
\text { Escalante River above Sand Creek, } \\
\text { includes Mamie Creek inflow } \\
\text { (Site 12) }\end{array}$ & $3.66 \mathrm{P}$ & $12.5 \mathrm{G}$ & $7.61 \mathrm{G}$ & 1.23 & 9.8 & 10.4 & $\mathrm{~N}$ & Jn \\
\hline 13 to 15 & $\begin{array}{l}\text { Escalante River above Sand Creek to } \\
\text { Escalante River above Calf Creek, } \\
\text { includes Sand Creek inflow (site 14) }\end{array}$ & $12.5 \mathrm{G}$ & $23.2 \mathrm{~F}$ & $11.6 \mathrm{G}$ & -.9 & -3.7 & -12.7 & $\mathrm{~N}$ & $\mathrm{Jn} / \mathrm{Jk}$ \\
\hline 15 to 19 & $\begin{array}{l}\text { Escalante River above Calf Creek to } \\
\text { Escalante River below Calf Creek, } \\
\text { includes Calf Creek inflow (site 18) }\end{array}$ & $23.2 \mathrm{~F}$ & $28.1 \mathrm{G}$ & $6.02 \mathrm{~F}$ & -1.12 & -3.8 & -12.8 & $\mathrm{~N}$ & $\mathrm{Jk}$ \\
\hline 20 to 29 & $\begin{array}{l}\text { Escalante River above Boulder Creek to } \\
\text { Escalante River above The Gulch (first } \\
\text { measurement), includes Boulder Creek } \\
\text { inflow (site 25) }\end{array}$ & $29.8 \mathrm{~F}$ & $59.8 \mathrm{~F}$ & $27.4 \mathrm{G}$ & 2.6 & 4.3 & 14.3 & $\mathrm{~N}$ & $\mathrm{Jn}$ \\
\hline 20 to 29 & $\begin{array}{l}\text { Escalante River above Boulder Creek to } \\
\text { Escalante River above The Gulch (second } \\
\text { measurement), includes Boulder Creek } \\
\text { inflow (site 25) }\end{array}$ & $29.8 \mathrm{~F}$ & $60.0 \mathrm{G}$ & $27.4 \mathrm{G}$ & 2.8 & 4.7 & 11.3 & $\mathrm{~N}$ & $\mathrm{Jn}$ \\
\hline \multicolumn{10}{|c|}{ October 24, 2001} \\
\hline 29 to 32 & $\begin{array}{l}\text { Escalante River above The Gulch (first } \\
\text { measurement) to Escalante River above } \\
\text { Horse Canyon, includes The Gulch inflow } \\
\text { (site 30) }\end{array}$ & $58.0 \mathrm{G}$ & $53.9 \mathrm{G}$ & e $.01 \mathrm{P}$ & -4.1 & -7.1 & -9.6 & $\mathrm{~N}$ & $\mathrm{Jn}$ \\
\hline 36 to 39 & $\begin{array}{l}\text { Escalante River above Harris Wash to } \\
\text { Escalante River above Fence Canyon, } \\
\text { includes Harris Wash inflow (site 37) }\end{array}$ & $55.9 \mathrm{G}$ & $61.4 \mathrm{G}$ & $1.54 \mathrm{P}$ & 3.96 & 6.4 & 9.8 & $\mathrm{~N}$ & $\mathrm{Jk} / \mathrm{JW}$ \\
\hline 39 to 44 & $\begin{array}{l}\text { Escalante River above Fence Canyon to } \\
\text { Escalante River above Twentyfive Mile }\end{array}$ & $61.4 \mathrm{G}$ & $64.8 \mathrm{~F}$ & $.07 \mathrm{P}$ & 3.33 & 5.1 & 12.7 & $\mathrm{~N}$ & $\mathrm{Jw}$ \\
\hline
\end{tabular}
Wash, includes Fence Canyon inflow (site 40) 


\section{Seepage Investigation and Selected Hydrologic Data, Garfield and Kane Counties, Utah, 1909-2002}

Table 2. Error analysis for data collected during seepage investigation along 15 reaches of the Escalante River between gaging station 09337500 and Stevens Canyon, Garfield and Kane Counties, Utah, October 2001—Continued

\begin{tabular}{|c|c|c|c|c|c|c|c|c|c|}
\hline $\begin{array}{c}\text { Site } \\
\text { number }\end{array}$ & Description of reach & $\mathbf{0}_{\mathbf{u s}}\left(\mathbf{f t}^{3} / \mathbf{s}\right)$ & $\mathbf{O}_{\mathrm{ds}}(\mathbf{f t} / \mathrm{s})$ & $\mathbf{0}_{\text {in }}\left(\mathbf{f t}^{3} / \mathbf{s}\right)$ & $\begin{array}{l}\text { Compu- } \\
\text { tation } \\
\text { of loss }(-) \\
\text { or gain }\end{array}$ & $\begin{array}{l}\text { Normalized } \\
\text { percentage } \\
\text { difference } \\
\left(\mathbf{N}_{\mathbf{d}} \%\right)\end{array}$ & $\begin{array}{l}\text { Normalized } \\
\text { percentage } \\
\text { error } \\
\left(\mathrm{N}_{\mathrm{e}} \%\right)\end{array}$ & $\begin{array}{l}\mathbf{N}_{\mathrm{d}} \%> \\
\mathbf{N}_{\mathrm{e}} \% \\
(\mathbf{Y} \text { or } \mathbf{N})\end{array}$ & Formation \\
\hline \multicolumn{10}{|c|}{ October 24, 2001-Continued } \\
\hline 44 to 47 & $\begin{array}{l}\text { Escalante River above Twentyfive Mile Wash } \\
\text { to Escalante River below Moody Creek, } \\
\text { includes Twentyfive Mile Wash inflow } \\
\text { (site 45) }\end{array}$ & $64.8 \mathrm{~F}$ & $61.9 \mathrm{~F}$ & $.5 \mathrm{P}$ & -3.4 & -5.2 & -15.6 & $\mathrm{~N}$ & JwTrc \\
\hline 47 to 49 & $\begin{array}{l}\text { Escalante River below Moody Creek to } \\
\text { Escalante River above Scorpion Gulch }\end{array}$ & $61.9 \mathrm{~F}$ & $62.1 \mathrm{G}$ & 0 & .2 & .3 & 13.0 & $\mathrm{~N}$ & $\operatorname{Trc}$ \\
\hline 49 to 55 & $\begin{array}{l}\text { Escalante River above Scorpion Gulch to } \\
\text { Escalante River } 3.7 \text { mi above Fools } \\
\text { Canyon, includes Scorpion Gulch inflow } \\
\text { (site 51) and estimate of tuning fork inflow } \\
\text { (site 53) (didn't land helicopter to measure } \\
\text { tuning fork inflow to avoid disturbing } \\
\text { campers near mouth as per special use } \\
\text { permit stipulations) }\end{array}$ & $62.1 \mathrm{G}$ & $61.3 \mathrm{G}$ & $\begin{array}{l}.02 \mathrm{P} \\
\mathrm{e} .5 \mathrm{P}\end{array}$ & -1.32 & -2.1 & -9.9 & $\mathrm{~N}$ & $\operatorname{Trc}$ \\
\hline 56 to 60 & $\begin{array}{l}\text { Escalante River above Fools Canyon to } \\
\text { Escalante River above Stevens Canyon, } \\
\text { includes Fools Canyon inflow (site 58) }\end{array}$ & $62.1 \mathrm{G}$ & $59.5 \mathrm{G}$ & e .002 & -2.6 & -4.2 & -9.8 & $\mathrm{~N}$ & $\operatorname{Trc} / \mathrm{Jw}$ \\
\hline
\end{tabular}


Table 3. Discharge, specific conductance, and temperature of water measured during seepage investigations along the Escalante River and tributaries, Garfield and Kane Counties, Utah, October 1981 and October 2001

[Site number: See plate 1 for location of sites. Description of site: USGS, U.S. Geological Survey; (09337500), station number of streamflow-gaging station operated by the USGS; Discharge: $\mathrm{ft}^{3} / \mathrm{s}$, cubic feet per second; e, estimated; Specific Conductance: $\mu \mathrm{S} / \mathrm{cm}$, microsiemens per centimeter at 25 degrees Celsius; Water Temperature: ${ }^{\circ} \mathrm{C}$, degrees Celsius; Formation: Jn, Jurassic Navajo Sandstone; Jk, Jurassic Kayenta Formation; Jw, Jurassic Wingate Sandstone; Trc, Triassic Chinle Formation; _, no data available; <, less than; ft, feet; mi, mile]

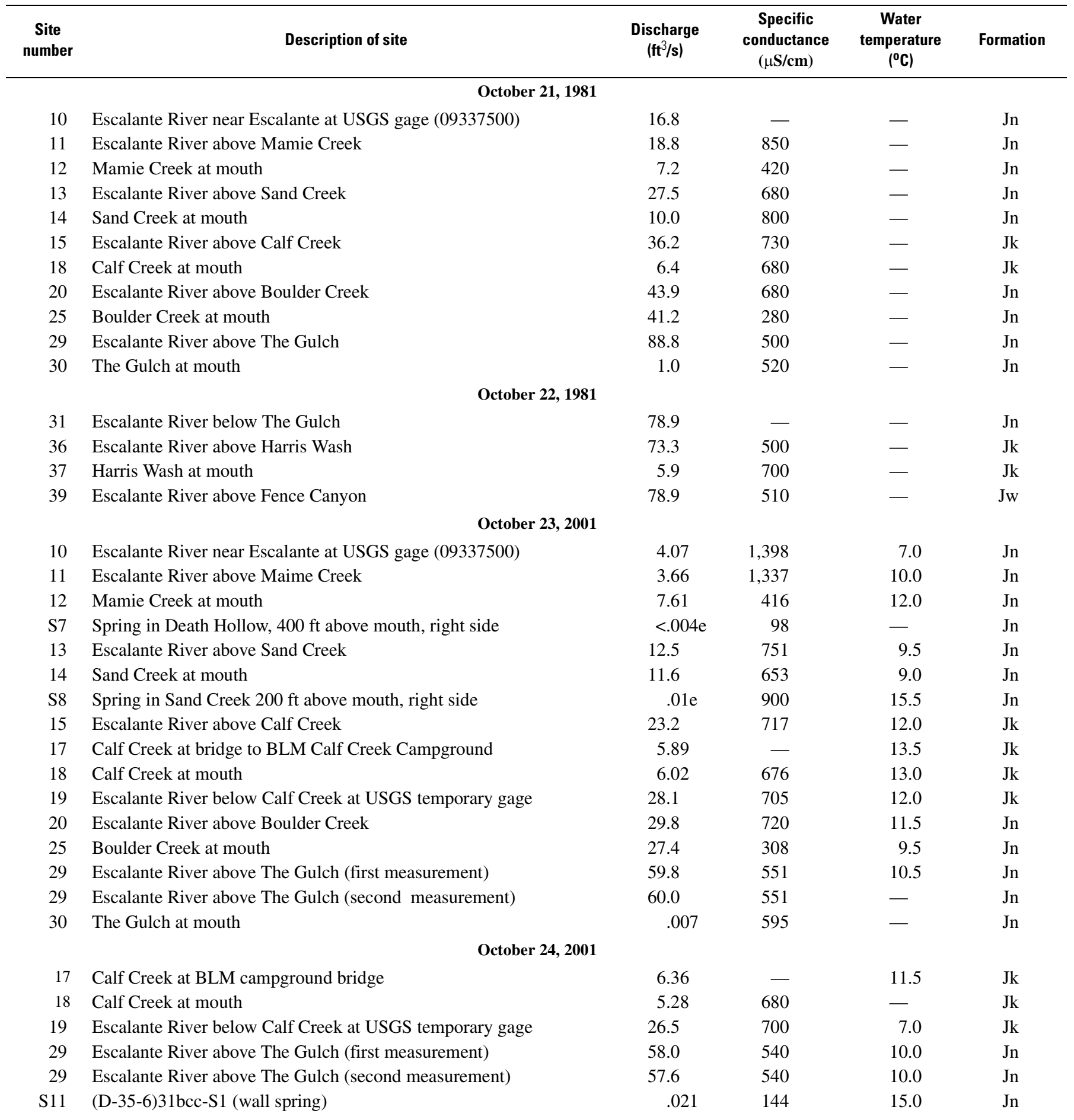




\section{Seepage Investigation and Selected Hydrologic Data, Garfield and Kane Counties, Utah, 1909-2002}

Table 3. Discharge, specific conductance, and temperature of water measured during seepage investigations along the Escalante River and tributaries, Garfield and Kane Counties, Utah, October 1981 and October 2001—Continued

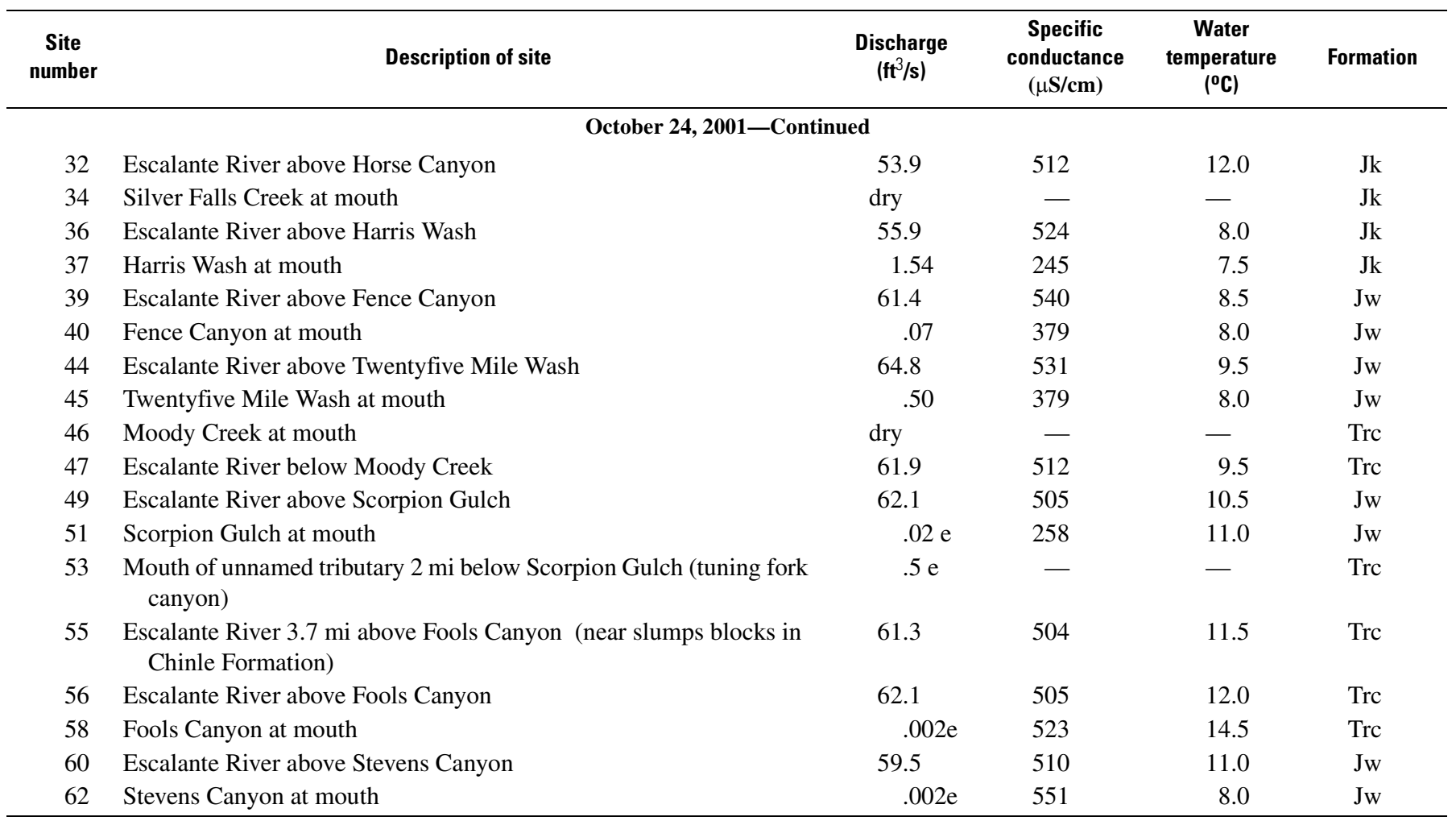


Table 4. Field measurements of specific conductance and water temperature from selected surface-water sites and springs in the Escalante River drainage basin, Garfield and Kane Counties, Utah, 1951-2002

[Site number: See plate 1 for location of sites; Description of site: See numbering system used for hydrologic-data sites in Utah for location of springs; Date: In year, month, day format; Specific conductance: $\mu \mathrm{S} / \mathrm{cm}$, microsiemens per centimeter at $25^{\circ}$ Celsius; Water temperature: ${ }^{\circ} \mathrm{C}$, degrees Celsius; - , no data; USGS, U.S. Geological Survey; BLM, Bureau of Land Management; mi, mile; ft, feet]

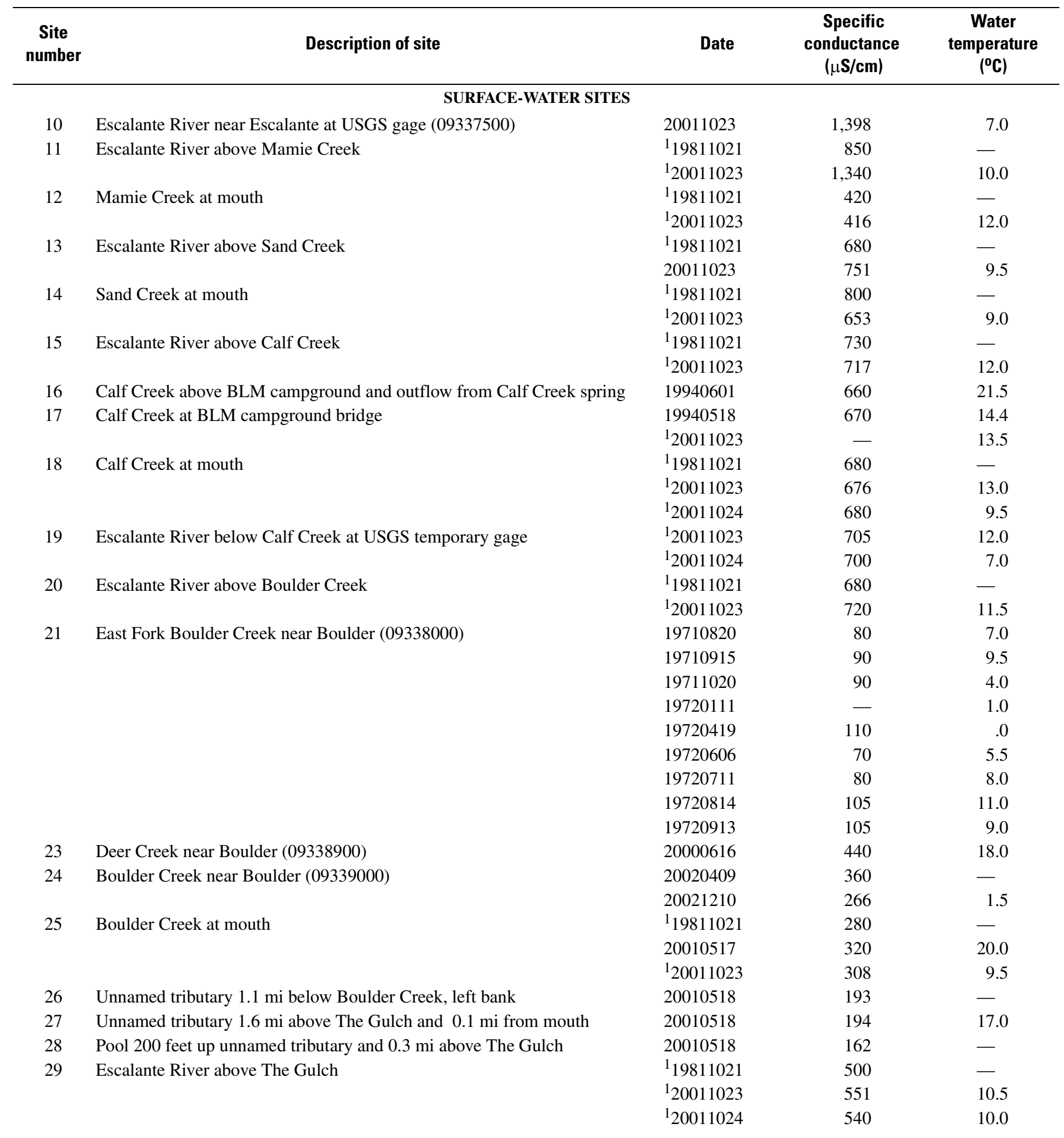




\section{Seepage Investigation and Selected Hydrologic Data, Garfield and Kane Counties, Utah, 1909-2002}

Table 4. Field measurements of specific conductance and water temperature from selected surface-water sites and springs in the Escalante River drainage basin, Garfield and Kane Counties, Utah, 1951-2002—Continued

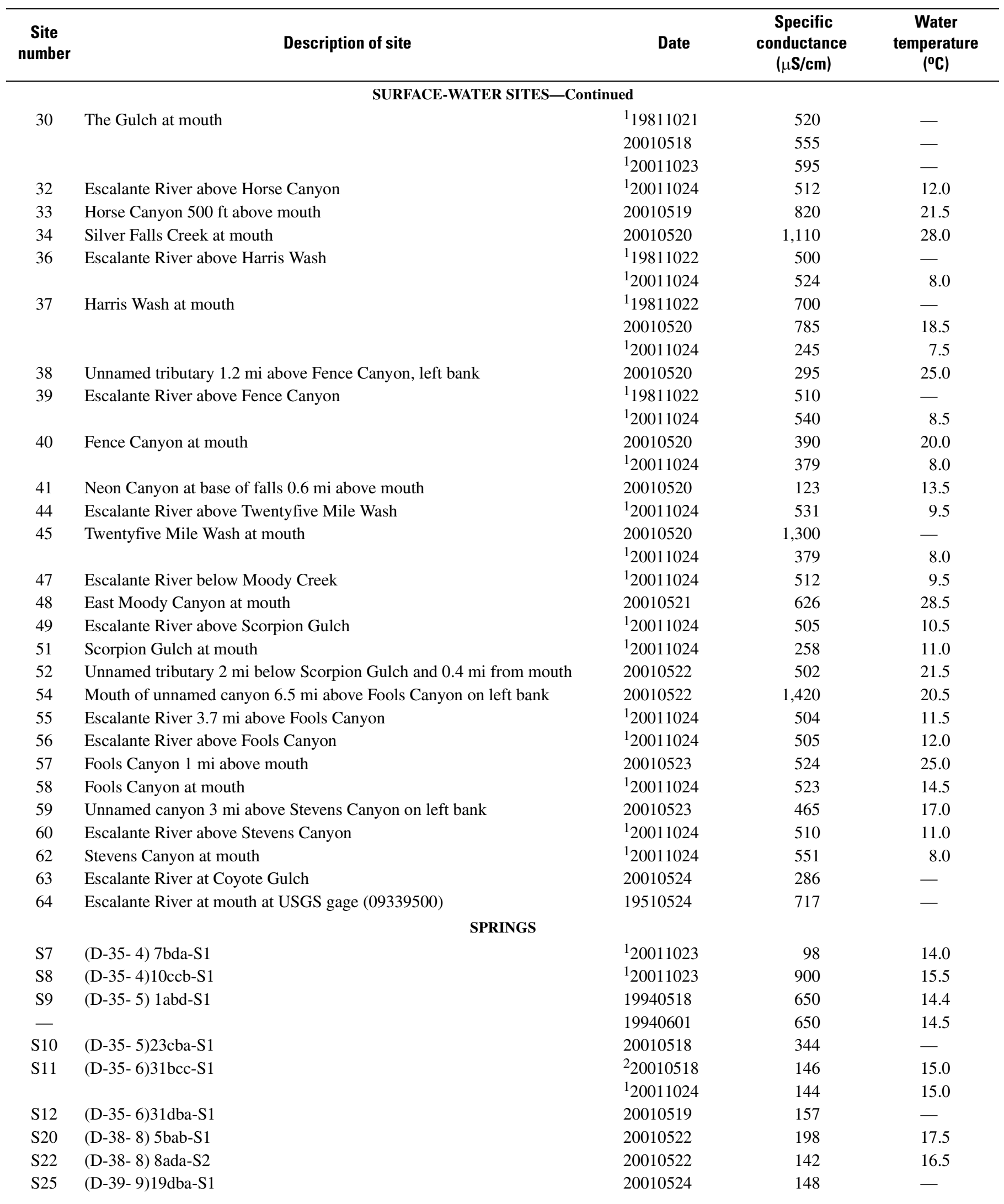


Table 4. Field measurements of specific conductance and water temperature from selected surface-water sites and springs in the Escalante River drainage basin, Garfield and Kane Counties, Utah, 1951-2002—Continued

\begin{tabular}{|c|c|c|c|c|}
\hline $\begin{array}{c}\text { Site } \\
\text { number }\end{array}$ & Description of site & Date & $\begin{array}{c}\text { Specific } \\
\text { conductance } \\
(\mu \mathrm{S} / \mathrm{cm})\end{array}$ & $\begin{array}{c}\text { Water } \\
\text { temperature } \\
\left({ }^{\circ} \mathrm{C}\right)\end{array}$ \\
\hline \multicolumn{5}{|c|}{ SPRINGS-Continued } \\
\hline $\mathrm{S} 26$ & (D-39- 9)19dcc-S1 & 20010524 & 160 & - \\
\hline $\mathrm{S} 27$ & (D-39- 9)20cad-S1 & 20010524 & 159 & - \\
\hline $\mathrm{S} 28$ & (D-39- 9)29aac-S1 & 20010524 & 169 & - \\
\hline
\end{tabular}

${ }^{1}$ Sample duplicated in table 3.

${ }^{2}$ Chemical analysis in table 12 . 
Table 5. Tritium concentration in water from selected surface-water sites and springs along the Escalante River and tributaries, Garfield and Kane Counties, Utah, 2001

[Analyses by Dissolved Gas Lab, University of Utah, Salt Lake City, Utah. Site number: See plate 1 for location of sites; Description of site: See numbering system used for hydrologic-data sites in Utah; Site ID: A unique number in the U.S. Geological Survey database that is used to identify a site and is based on the latitude (first 6 digits) and longitude (last 7 digits) of the site. 1927 North American Datum (NAD 1927); Date and time sampled: month, day, year and 24-hour time that sample was collected; Formation: Qt, Quaternary rockfall talus; Jn, Jurassic Navajo Sandstone; Jk, Jurassic Kayenta Formation; Jw, Jurassic Wingate Formation; Trc, Triassic Chinle Formation; Tritium units: represents one molecule of ${ }^{3} \mathrm{H}^{1} \mathrm{HO}$ in $10^{18}$ molecules of $\mathrm{H}_{2} \mathrm{O}$; ft, feet; mi, mile]

\begin{tabular}{|c|c|c|c|c|c|c|c|}
\hline \multirow{2}{*}{$\begin{array}{c}\text { Site } \\
\text { number }\end{array}$} & \multirow{2}{*}{ Description of site } & \multirow{2}{*}{ Site ID } & \multirow{2}{*}{$\begin{array}{l}\text { Date and time } \\
\text { sampled }\end{array}$} & \multirow{2}{*}{ Formation } & \multirow{2}{*}{$\begin{array}{c}\text { Tritium } \\
\text { units }\end{array}$} & \multicolumn{2}{|c|}{$\begin{array}{l}\text { Uncertainty of analysisin } \\
\text { Tritium Units }\end{array}$} \\
\hline & & & & & & Plus & Minus \\
\hline S20 & $\begin{array}{l}\text { Spring in fracture } 300 \mathrm{ft} \text { above Scorpion Gulch, } \\
\text { right bank } \\
(\mathrm{D}-38-8) 5 \mathrm{bab}-\mathrm{S} 1\end{array}$ & 3731441110350 & $05-22-01$ at $0940 \mathrm{hrs}$ & $\mathrm{Jw}$ & 0.53 & 0.03 & 0.06 \\
\hline 50 & Stream in Scorpion Gulch near mouth & 3731381110345 & $05-21-01$ at $2000 \mathrm{hrs}$ & Jw & 1.20 & .06 & .10 \\
\hline S21 & $\begin{array}{l}\text { Spring } 1 \text { mi below Scorpion Gulch, right bank } \\
\text { (D-38-8)8ada-S1 }\end{array}$ & 3731321110318 & $05-22-01$ at $1130 \mathrm{hrs}$ & $\mathrm{JW} / \mathrm{Trc}$ & .05 & .01 & .02 \\
\hline 52 & Stream in tuning fork canyon & 3732041110232 & $05-22-01$ at $1530 \mathrm{hrs}$ & $\mathrm{Jw}$ & 3.81 & .19 & .19 \\
\hline S23 & $\begin{array}{l}\text { Spring in tuning fork canyon } \\
\text { (D-38-8)4dbc-S1 }\end{array}$ & 3732041110231 & $05-22-01$ at $1630 \mathrm{hrs}$ & $\mathrm{Jw} / \mathrm{Qt}$ & 4.17 & .21 & .21 \\
\hline 57 & Stream in Fools Canyon 1 mi above mouth & 3727571110046 & $05-23-01$ at $1500 \mathrm{hrs}$ & $\mathrm{Jw}$ & 2.72 & .23 & .47 \\
\hline 61 & Stream in Stevens Canyon near mouth & 3726081105838 & $05-24-01$ at $1105 \mathrm{hrs}$ & $\mathrm{Jw}$ & 5.48 & .27 & .27 \\
\hline S24 & $\begin{array}{l}\text { Spring in Coyote Gulch, left bank } \\
\text { (D-39-8)13bab-S1 }\end{array}$ & 3725371105936 & $05-24-01$ at $1400 \mathrm{hrs}$ & $\mathrm{Jn} / \mathrm{Jk}$ & .30 & .07 & .13 \\
\hline S26 & $\begin{array}{l}\text { Spring about } 4 \text { mi below Coyote Gulch, right } \\
\text { bank } \\
\text { (D-39-9)19dcc-S1 }\end{array}$ & 3724001105809 & $05-24-01$ at $1755 \mathrm{hrs}$ & $\mathrm{Jn} / \mathrm{Jk}$ & .39 & .02 & .02 \\
\hline S28 & $\begin{array}{l}\text { Spring } 5.7 \text { mi below Coyote Gulch, left bank } \\
\text { (D-39-9)29ac-S1 }\end{array}$ & 3723451105651 & $05-24-01$ at $1830 \mathrm{hrs}$ & $\mathrm{Jn} / \mathrm{Jk}$ & .04 & .00 & .01 \\
\hline
\end{tabular}


Table 6. Chlorofluorocarbon concentration in water from selected surface-water sites and springs along the Escalante River and tributaries, Garfield and Kane Counties, Utah, 2001

[Analysis by Dissolved Gas Lab, University of Utah, Salt Lake City, Utah; Site number: See plate 1 for location of sites. Sample was divided into three equal volumes, a, b, and c, for individual laboratory analysis; Description of site: See numbering system used for hydrologic-data sites in Utah; Site ID: A unique number in the U.S. Geological Survey database that is used to identify a site and is based on the latitude (first 6 digits) and longitude (last 7 digits) of the site. 1927 North American Datum (NAD 1927); Date sampled: in month, day, year format; Formation: Qt, Quaternary rockfall talus; Jn, Jurassic Navajo Sandstone; Jk, Jurassic Kayenta Formation; Jw, Jurassic Wingate Sandstone; Trc, Triassic Chinle Formation; CFC-11 concentration: Chlorofluorocarbon-11 (CCl2F); CFC-12 concentration: Chlorofluorocarbon-12 (CCl2F2); pmoles/kg, picomoles per kilogram; mi, mile]

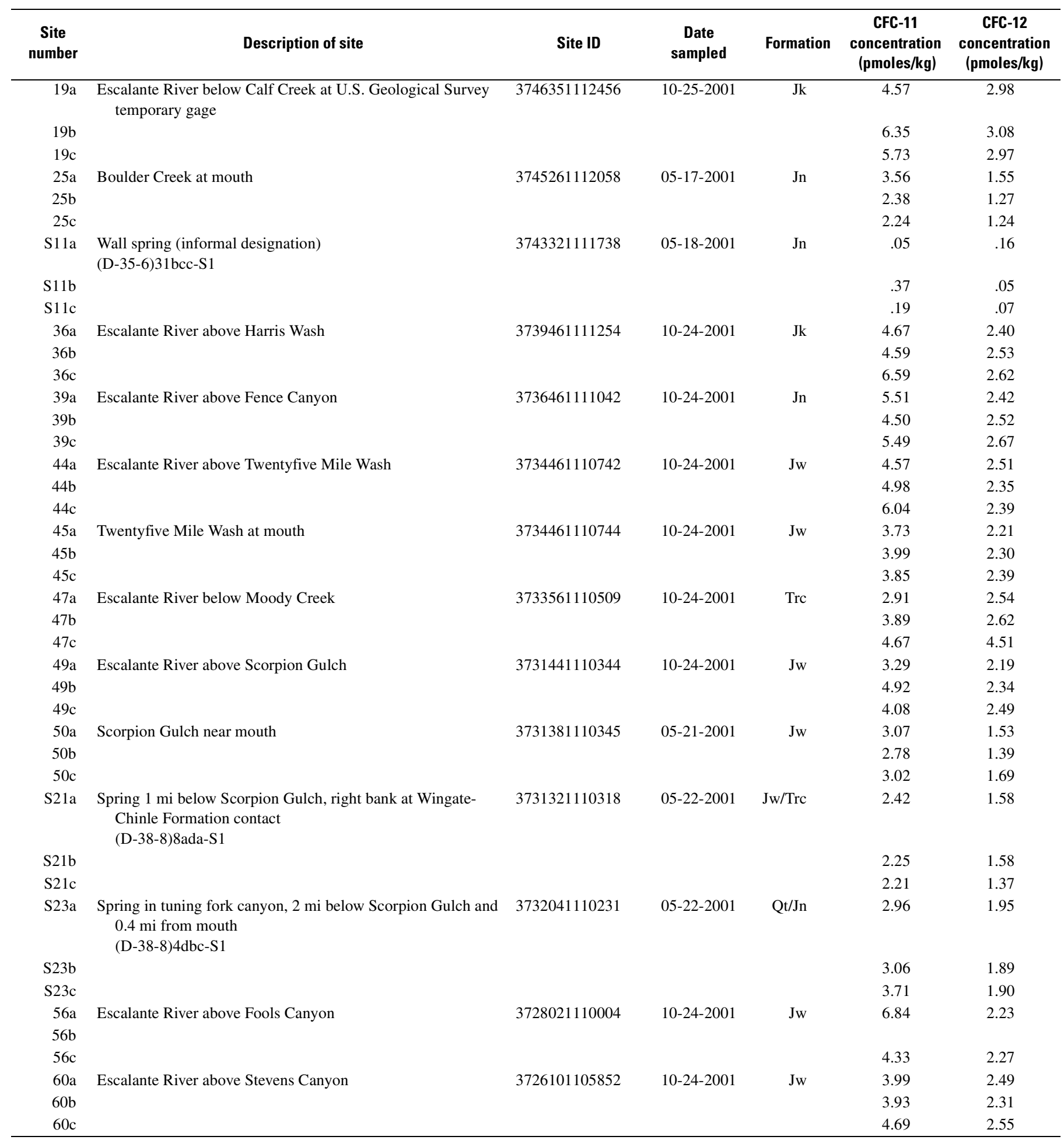


Table 7. Selected data for gaging stations in the Escalante River drainage basin, Garfield and Kane Counties, 1909-2002

[Site number: See plate 1 for location of streamflow-gaging stations; Description of site: General description of active or discontinued gaging station; Source of data: USGS, U.S. Geological Survey; SWR, Surface Water Records of Utah, USGS-published surface-water data from 1961 to 1969; TP, Technical Publication, reports prepared by the USGS in cooperation with Utah State agencies, typically Department of Natural Resources, Division of Water Rights; WDR, Water Data Report, USGS-published water-data reports since 1975; WRD, Water Resources Data, USGS-published water data reports from 1965-74; WSP, Water-Supply Paper, USGS-published report series; $\mathrm{ft}^{3}$ /s, cubic feet per second; approx., approximately; —, no data; mi, miles; mm-dd-yyyy, month, day, year]

\begin{tabular}{|c|c|c|c|c|c|}
\hline $\begin{array}{l}\text { Site } \\
\text { num- } \\
\text { ber }\end{array}$ & $\begin{array}{l}\text { Gaging } \\
\text { station } \\
\text { number }\end{array}$ & Description of site & Period of record & $\begin{array}{l}\text { Drainage } \\
\text { area } \\
\text { (square } \\
\text { miles) }\end{array}$ & $\begin{array}{l}\text { Annual } \\
\text { mean } \\
\text { discharge } \\
\left(\mathrm{ft}^{3} / \mathbf{s}\right)\end{array}$ \\
\hline 1 & 09335500 & North Creek near Escalante & Jul 1950-Sep 1955 & 90 & 7.64 \\
\hline 3 & 09336000 & Birch Creek near Escalante & $\begin{array}{l}\text { Jul 1950-Sep 1951, Annual } \\
\quad \text { peaks } 1959-74\end{array}$ & 36 & .54 \\
\hline 7 & 09336500 & Birch Creek at mouth, near Escalante & Oct 1951-Jul 1955 & 100 & 3.26 \\
\hline 9 & 09337000 & Pine Creek near Escalante ${ }^{4}$ & $\begin{array}{l}\text { Jul 1950-Sep 1955, } \\
\text { Jul 1957-Sep } 2002\end{array}$ & 78 & 5.15 \\
\hline 10 & 09337500 & Escalante River near Escalante ${ }^{4}$ & $\begin{array}{l}\text { Aug 1909-Apr } 1913 \\
\text { Oct 1942-Sep 1955, } \\
\text { Dec 1971-Sep } 2002\end{array}$ & 310 & 11.0 \\
\hline 22 & 09338500 & East Fork Deer Creek near Boulder & Jul 1950-Sep 1955 & 1.9 & 1.39 \\
\hline 23 & 09338900 & Deer Creek near Boulder ${ }^{4}$ & Annual peaks $1959-74$ & 63 & - \\
\hline 24 & 09339000 & Boulder Creek near Boulder ${ }^{4}$ & Jul 1950-Sep $1955^{8}$ & 175 & 23.0 \\
\hline 43 & 09339200 & Twentymile Wash near Escalante & Annual peaks $1959-68$ & 140 & - \\
\hline 64 & 09339500 & $\begin{array}{l}\text { Escalante River at mouth near Escalante (approx } 2.2 \text { mi below } \\
\text { Davis Gulch and } 5.1 \text { mi above confluence with Colorado River } \\
\text { left bank, site inundated by Lake Powell June 1963) }\end{array}$ & Apr 1951-Sep 1955 & 1,770 & 85.2 \\
\hline
\end{tabular}

${ }^{1}$ No flow for part of each day August 6, 1951; November 25-27, 1952; December 1, 1953.

${ }^{2}$ No flow at times.

${ }^{3}$ Some flow throughout most years, but dry on occasions.

${ }^{4}$ Active gaging station.

${ }^{5}$ No flow at times some years.

${ }^{6}$ No flow for part of day as result of freeze up.

${ }^{7}$ Gage reactivated in September 2001.

${ }^{8}$ Gage reactivated in December 2002.

${ }^{9}$ Only intermittent or ephemeral flow.

${ }^{10}$ Miscellaneous discharge measurements and water samples were obtained at the mouth of the Escalante River during river reconnaissance trips from Linwood, Utah, to Lee's Ferry, Arizona, by USGS on October 15, 1946; September 24, 1947; and October 5, 1948 (H.W. Chase, District Engineer, written commun., 1948). 
Table 7. Selected data for gaging stations in the Escalante River drainage basin, Garfield and Kane Counties, 1909-2002—Continued

\begin{tabular}{|c|c|c|c|c|c|c|c|}
\hline \multirow[b]{2}{*}{$\begin{array}{c}\text { Site } \\
\text { num- } \\
\text { ber }\end{array}$} & \multirow{2}{*}{$\begin{array}{c}\text { Number of } \\
\text { water years } \\
\text { used to } \\
\text { calculate } \\
\text { annual } \\
\text { mean }\end{array}$} & \multirow[b]{2}{*}{$\begin{array}{l}\text { Gaging station } \\
\text { number }\end{array}$} & \multicolumn{4}{|c|}{ Extremes } & \multirow[b]{2}{*}{$\begin{array}{c}\text { Source of } \\
\text { data }\end{array}$} \\
\hline & & & $\begin{array}{c}\text { Maximum } \\
\text { discharge }\left(\mathrm{ft}^{3} / \mathrm{s}\right)\end{array}$ & $\begin{array}{c}\text { Date of } \\
\text { maximum } \\
\text { discharge } \\
\text { (mm-dd-yy) }\end{array}$ & $\begin{array}{c}\text { Minimum } \\
\text { discharge }\left(\mathrm{ft}^{3} / \mathrm{s}\right)\end{array}$ & $\begin{array}{c}\text { Date of } \\
\text { minimum } \\
\text { discharge } \\
\text { (mm-dd-yy) }\end{array}$ & \\
\hline 1 & 5 & 09335500 & 3,610 & $08-21-52$ & 0 & (1) & WSP 1733, TP 21 \\
\hline 2 & 1 & 09336000 & 3,400 & $08-19-63$ & 0 & (2) & WSP 1733, SWR 1963 \\
\hline 7 & 3 & 09336500 & 1,010 & $07-12-54$ & .1 & \multirow{2}{*}{$\begin{array}{l}07-13-55 \text { and } 07-14-55 \\
\text { (5) }\end{array}$} & WSP 1733 \\
\hline 9 & 50 & 09337000 & 1,010 & $08-02-67$ & 0 & & WRD 1967 \\
\hline 10 & 46 & 09337500 & 4,550 & $08-24-98$ & 0.07 & $12-24-78$ & WDR-UT-98-1 \\
\hline 23 & - & 09338900 & 3,820 & 08-03-61 & 0 & (3) & ${ }^{7}$ SWR 1962 \\
\hline 24 & 5 & 09339000 & 4,650 & $07-25-55$ & 6.1 & \multirow{2}{*}{$\begin{array}{l}06-26-53 \\
\text { (9) }\end{array}$} & WSP 1733 \\
\hline 43 & - & 09339200 & 4,620 & $08-27-63$ & 0 & & SWR 1963 \\
\hline 64 & 5 & 09339500 & 14,600 & $08-04-51$ & 4.4 & $08-20-50$ and $07-11-51$ & ${ }^{10}$ WSP 1733 \\
\hline
\end{tabular}


Table 8. Field measurements of specific conductance and water temperature at gaging station at Pine Creek near Escalante (09337000, site 9), Garfield County, Utah, 1971-91

[Record number: A unique number that identifies one water-quality sample in the U.S. Geological Survey data base. See plate 1 for location of gaging station 09337000; Date: in year, month, day format; Specific conductance: $\mu \mathrm{S} / \mathrm{cm}$, microsiemens per centimeter at $25^{\circ} \mathrm{Celsius;} \mathrm{Water} \mathrm{temperature:}{ }^{\circ} \mathrm{C}$, degrees Celsius; - , no data]

\begin{tabular}{|c|c|c|c|c|c|c|c|}
\hline Record number & Date & $\begin{array}{c}\text { Specific } \\
\text { conductance } \\
(\mu \mathrm{S} / \mathrm{cm})\end{array}$ & $\begin{array}{c}\text { Water } \\
\text { temperature } \\
\left({ }^{\circ} \mathrm{C}\right)\end{array}$ & Record number & Date & $\begin{array}{c}\text { Specific } \\
\text { conductance } \\
(\mu S / \mathrm{cm})\end{array}$ & $\begin{array}{c}\text { Water } \\
\text { temperature } \\
\left({ }^{\circ} \mathrm{C}\right)\end{array}$ \\
\hline 97100373 & 19710819 & 340 & 19.0 & 97601505 & 19760527 & 245 & 10.5 \\
\hline 97100374 & 19710915 & 400 & 13.5 & 97601506 & 19760701 & 240 & 18.0 \\
\hline 97200857 & 19711021 & 400 & 1.0 & 97601507 & 19760805 & 260 & 21.0 \\
\hline 97200859 & 19720217 & 340 & 0.0 & 97701409 & 19761011 & 350 & 8.0 \\
\hline 97200860 & 19720323 & 360 & 9.0 & 97701410 & 19761109 & 345 & 7.0 \\
\hline 97200861 & 19720418 & 400 & 11.0 & 97701411 & 19770104 & 325 & .5 \\
\hline 97200862 & 19720512 & 220 & 4.0 & 97701412 & 19770228 & 400 & 3.0 \\
\hline 97200863 & 19720605 & 255 & 15.0 & 97801337 & 19771004 & 420 & 22.0 \\
\hline 97200864 & 19720711 & 250 & 22.5 & 97801338 & 19771109 & 420 & 2.0 \\
\hline 97200865 & 19720814 & 360 & 17.5 & 97801339 & 19780112 & 420 & .0 \\
\hline 97200866 & 19720913 & 340 & 14.0 & 97801340 & 19780321 & 350 & 5.5 \\
\hline 97300980 & 19721018 & 340 & 7.5 & 97801341 & 19780426 & 420 & 11.5 \\
\hline 97300981 & 19721018 & 340 & 7.5 & 97801342 & 19780602 & 250 & 11.0 \\
\hline 97300982 & 19721129 & 400 & .0 & 97801343 & 19780710 & 225 & 22.0 \\
\hline 97300983 & 19721129 & 400 & .0 & 97801344 & 19780809 & 220 & 20.0 \\
\hline 97300984 & 19730108 & 375 & .0 & 97801345 & 19780911 & 390 & 20.0 \\
\hline 97300985 & 19730108 & 375 & .0 & 97901219 & 19781004 & 340 & 15.5 \\
\hline 97300986 & 19730418 & 360 & 4.0 & 97901220 & 19781107 & 350 & 9.0 \\
\hline 97300987 & 19730509 & 380 & 9.5 & 97901221 & 19781212 & 455 & 1.5 \\
\hline 97300988 & 19730613 & 280 & 11.5 & 97901222 & 19790418 & 400 & 5.0 \\
\hline 97300989 & 19730710 & 380 & 19.0 & 97901223 & 19790515 & 400 & 8.0 \\
\hline 97400862 & 19731002 & 350 & 5.0 & 97901224 & 19790612 & 405 & 15.0 \\
\hline 97400863 & 19731213 & 300 & .5 & 97901225 & 19790717 & 390 & 20.0 \\
\hline 97400864 & 19740214 & 320 & .5 & 97901226 & 19790822 & 350 & 16.5 \\
\hline 97400865 & 19740319 & 350 & 8.5 & 97901227 & 19790920 & 275 & 12.0 \\
\hline 97400866 & 19740501 & 370 & 13.0 & 98001344 & 19791004 & 350 & 13.0 \\
\hline 97400867 & 19740606 & 300 & 11.0 & 98001345 & 19791115 & 380 & 7.0 \\
\hline 97400868 & 19740710 & 220 & 21.0 & 98001346 & 19800408 & 380 & 4.0 \\
\hline 97400869 & 19740828 & 340 & 13.0 & 98001347 & 19800506 & 350 & 3.0 \\
\hline 97501693 & 19741009 & 315 & 8.0 & 98001348 & 19800624 & 390 & 18.0 \\
\hline 97501694 & 19741205 & 380 & .5 & 98001349 & 19800806 & 380 & 18.0 \\
\hline 97501695 & 19750128 & 320 & .0 & 98101259 & 19801006 & 345 & 14.0 \\
\hline 97501696 & 19750228 & 340 & .0 & 98101260 & 19801201 & 310 & .5 \\
\hline 97501697 & 19750508 & 440 & 10.0 & 98101261 & 19810114 & 330 & .5 \\
\hline 97501698 & 19750702 & 445 & 21.0 & 98101262 & 19810324 & 375 & 8.5 \\
\hline 97501699 & 19750731 & 295 & 21.5 & 98101263 & 19810421 & - & 7.0 \\
\hline 97501700 & 19750904 & 345 & 20.0 & 98101264 & 19810519 & 375 & 11.0 \\
\hline 97601498 & 19751010 & 375 & 9.5 & 98101265 & 19810624 & 225 & 14.0 \\
\hline 97601499 & 19751119 & 360 & .5 & 98101266 & 19810715 & 310 & 15.0 \\
\hline 97601500 & 19751211 & 380 & .5 & 98101267 & 19810903 & 370 & 16.0 \\
\hline 97601501 & 19760122 & 365 & .0 & 98200773 & 19811008 & 370 & 6.0 \\
\hline 97601502 & 19760204 & 370 & .0 & 98200774 & 19811117 & 375 & 3.0 \\
\hline 97601503 & 19760311 & 355 & .5 & 98200775 & 19811216 & 385 & .5 \\
\hline 97601504 & 19760421 & 55 & 10.0 & 98200776 & 19820114 & 400 & .5 \\
\hline
\end{tabular}


Table 8. Field measurements of specific conductance and water temperature at gaging station at Pine Creek near Escalante (09337000, site 9), Garfield County, Utah, 1971-91—Continued

\begin{tabular}{|c|c|c|c|}
\hline Record number & Date & $\begin{array}{c}\text { Specific } \\
\text { conductance } \\
(\mu \mathrm{S} / \mathrm{cm})\end{array}$ & $\begin{array}{c}\text { Water } \\
\text { temperature } \\
\left({ }^{\circ} \mathrm{C}\right)\end{array}$ \\
\hline 98200777 & 19820222 & 390 & 1.0 \\
\hline 98200778 & 19820331 & 440 & 6.0 \\
\hline 98200779 & 19820429 & 195 & 5.5 \\
\hline 98200780 & 19820520 & 180 & 9.0 \\
\hline 98200781 & 19820623 & 400 & 10.5 \\
\hline 98200782 & 19820722 & 310 & 18.0 \\
\hline 98200783 & 19820817 & 345 & 18.0 \\
\hline 98301022 & 19821007 & 365 & 3.0 \\
\hline 98301023 & 19821115 & 445 & .5 \\
\hline 98301024 & 19821228 & 270 & .5 \\
\hline 98301025 & 19830126 & 400 & 6.0 \\
\hline 98301026 & 19830307 & 395 & .5 \\
\hline 98301027 & 19830415 & 435 & 2.0 \\
\hline 98301028 & 19830518 & 470 & 3.0 \\
\hline 98301029 & 19830620 & 330 & 12.0 \\
\hline 98301030 & 19830809 & 370 & 17.0 \\
\hline 98301031 & 19830920 & 335 & 7.0 \\
\hline 98401607 & 19831018 & 370 & 8.0 \\
\hline 98401608 & 19831207 & 385 & .5 \\
\hline 98401609 & 19840112 & 410 & .5 \\
\hline 98401610 & 19840209 & 390 & .5 \\
\hline 98401611 & 19840312 & 400 & 3.0 \\
\hline 98401612 & 19840412 & 435 & 7.0 \\
\hline 98401613 & 19840510 & 160 & 9.5 \\
\hline 98401614 & 19840613 & 400 & 10.5 \\
\hline 98401615 & 19840718 & 320 & 23.0 \\
\hline 98401616 & 19840822 & 285 & 15.5 \\
\hline 98601853 & 19851016 & 385 & 8.0 \\
\hline 98601854 & 19851129 & 370 & .5 \\
\hline 98601855 & 19860117 & 390 & 1.0 \\
\hline 98601856 & 19860311 & 415 & 5.0 \\
\hline 98601857 & 19860424 & 310 & 6.5 \\
\hline 98601858 & 19860602 & 320 & 15.0 \\
\hline 98601859 & 19860701 & 275 & - \\
\hline 98601860 & 19860818 & 235 & 20.0 \\
\hline 98802136 & 19871008 & 390 & 8.5 \\
\hline 98802137 & 19871201 & - & 1.0 \\
\hline 98802138 & 19880210 & 425 & 1.0 \\
\hline 98802139 & 19880406 & - & 6.0 \\
\hline 98802140 & 19880505 & 335 & - \\
\hline 98802141 & 19880610 & - & 14.5 \\
\hline 98802142 & 19880713 & - & 17.0 \\
\hline 98802143 & 19880826 & 260 & 17.0 \\
\hline 98900833 & 19881103 & 380 & 5.0 \\
\hline 98900834 & 19881207 & 390 & 4.0 \\
\hline 98900835 & 19890214 & - & 1.0 \\
\hline 98902431 & 19890404 & - & 12.5 \\
\hline 98900837 & 19890503 & 370 & 11.0 \\
\hline
\end{tabular}

\begin{tabular}{lccc}
\hline Record number & Date & $\begin{array}{c}\text { Specific } \\
\text { conductance } \\
(\mu \text { S/cm) }\end{array}$ & $\begin{array}{c}\text { Water } \\
\text { temperature } \\
\left({ }^{\circ} \mathbf{C}\right)\end{array}$ \\
\hline 98902449 & 19890607 & 320 & 17.0 \\
98902450 & 19890713 & 405 & 23.0 \\
98902451 & 19890811 & 385 & 20.0 \\
98902452 & 19890912 & 390 & 13.5 \\
99000224 & 19891005 & 395 & 10.5 \\
99000631 & 19891101 & 440 & 10.0 \\
99000632 & 19891207 & 430 & 10.0 \\
99000633 & 19900118 & - & 1.0 \\
99000634 & 19900301 & 445 & .0 \\
99000986 & 19900304 & 425 & 7.0 \\
99000987 & 19900426 & 490 & 10.0 \\
99001690 & 19900601 & 440 & 9.0 \\
99001691 & 19900720 & 430 & 19.0 \\
99002015 & 19900821 & 450 & 16.0 \\
99101372 & 19901018 & 425 & 7.5 \\
99101373 & 19901129 & 550 & .5 \\
99101374 & 19910123 & - & .2 \\
99101375 & 19910220 & 450 & .0 \\
99101376 & 19910328 & 475 & 2.0 \\
99101377 & 19910424 & 450 & 3.5 \\
99101378 & 19910515 & 235 & 9.5 \\
99101379 & 19910618 & 285 & 16.0 \\
99101380 & 19910716 & 225 & 20.5 \\
99101831 & 19910820 & 410 & 14.0 \\
\hline & & & \\
\hline
\end{tabular}


Table 9. Field measurements of specific conductance and water temperature at gaging station at Escalante River near Escalante (09337500, site 10), Garfield County, Utah, 1969-2001

[Record number: A unique number that identifies one water-quality sample in the U.S. Geological Survey data base. See plate 1 for location of gaging station 09337500; Date: In year, month, date format; Specific conductance: $\mu \mathrm{S} / \mathrm{cm}$, microsiemens per centimeter at $25^{\circ}$ Celsius; Water temperature: ${ }^{\circ} \mathrm{C}$, degrees Celsius; - , no data]

\begin{tabular}{|c|c|c|c|}
\hline Record number & Date & $\begin{array}{c}\text { Specific } \\
\text { conductance } \\
(\mu \mathrm{S} / \mathrm{cm})\end{array}$ & $\begin{array}{c}\text { Water } \\
\text { temperature } \\
\left({ }^{\circ} \mathrm{C}\right)\end{array}$ \\
\hline 96900543 & 19690806 & 700 & 22.0 \\
\hline 96900544 & 19690806 & 700 & 22.0 \\
\hline 97000373 & 19691211 & 280 & .0 \\
\hline 97000376 & 19700820 & 800 & 17.0 \\
\hline 97100375 & 19701112 & 800 & 7.0 \\
\hline 97100376 & 19701112 & 845 & 7.0 \\
\hline 97100378 & 19710406 & 758 & - \\
\hline 97200867 & 19711203 & 825 & 1.5 \\
\hline 97200869 & 19720606 & 610 & 26.0 \\
\hline 97300990 & 19721018 & 1,400 & 11.5 \\
\hline 97300991 & 19721129 & 1,540 & 3.5 \\
\hline 97300992 & 19730322 & 1,350 & 8.0 \\
\hline 97300993 & 19730418 & 950 & 6.0 \\
\hline 97300994 & 19730509 & 480 & 19.0 \\
\hline 97300995 & 19730613 & 470 & 15.0 \\
\hline 97300996 & 19730809 & 1,200 & 28.0 \\
\hline 97400870 & 19731002 & 940 & 11.5 \\
\hline 97400871 & 19731101 & 1,380 & 12.0 \\
\hline 97400872 & 19731213 & 925 & 2.0 \\
\hline 97400873 & 19740214 & 750 & .5 \\
\hline 97400874 & 19740319 & 850 & 11.0 \\
\hline 97400875 & 19740502 & 1,900 & 7.0 \\
\hline 97400876 & 19740605 & 1,800 & 20.0 \\
\hline 97400877 & 19740828 & 2,200 & 20.0 \\
\hline 97501701 & 19741009 & 1,600 & 14.0 \\
\hline 97501702 & 19741205 & 2,000 & 6.0 \\
\hline 97501703 & 19750402 & 2,100 & .0 \\
\hline 97501704 & 19750508 & 2,000 & 19.0 \\
\hline 97501705 & 19750702 & 2,300 & 26.5 \\
\hline 97501706 & 19750801 & 2,000 & 12.0 \\
\hline 97501707 & 19750905 & 2,150 & 10.0 \\
\hline 97601508 & 19751008 & 2,000 & 2.5 \\
\hline 97601509 & 19751119 & 1,600 & 7.0 \\
\hline 97601510 & 19751211 & 1,100 & 5.5 \\
\hline 97601511 & 19760123 & 1,280 & .0 \\
\hline 97601512 & 19760204 & 850 & .5 \\
\hline 97601513 & 19760311 & 1,100 & 1.0 \\
\hline 97601514 & 19760422 & 1,850 & 6.0 \\
\hline 97601515 & 19760527 & 1,550 & 12.0 \\
\hline 97601516 & 19760701 & 2,000 & 20.5 \\
\hline 97601517 & 19760806 & 2,300 & 15.0 \\
\hline 97601518 & 19760831 & 2,050 & 24.5 \\
\hline 97701413 & 19761011 & 1,320 & 10.0 \\
\hline 97701414 & 19761109 & 1,300 & 13.0 \\
\hline 97701415 & 19770228 & 1,400 & 8.0 \\
\hline
\end{tabular}

\begin{tabular}{|c|c|c|c|}
\hline Record number & Date & $\begin{array}{c}\text { Specific } \\
\text { conductance } \\
(\mu \mathrm{S} / \mathrm{cm})\end{array}$ & $\begin{array}{c}\text { Water } \\
\text { temperature } \\
\left({ }^{\circ} \mathrm{C}\right)\end{array}$ \\
\hline 97701416 & 19770523 & 2,000 & 19.0 \\
\hline 97701417 & 19770705 & 1,900 & 24.0 \\
\hline 97701418 & 19770809 & 1,850 & 28.0 \\
\hline 97801346 & 19771004 & 1,700 & 8.0 \\
\hline 97801347 & 19771109 & 1,550 & 5.5 \\
\hline 97801348 & 19780111 & 1,550 & - \\
\hline 97801349 & 19780112 & 1,720 & .0 \\
\hline 97801350 & 19780222 & 1,250 & .5 \\
\hline 97801351 & 19780602 & 1,500 & 15.5 \\
\hline 97801352 & 19780710 & 3,000 & 25.0 \\
\hline 97801353 & 19780810 & 1,400 & 15.0 \\
\hline 97801354 & 19780911 & 1,500 & 23.0 \\
\hline 97901228 & 19781004 & 1,450 & - \\
\hline 97901229 & 19781107 & 1,050 & 13.5 \\
\hline 97901230 & 19781212 & 1,340 & .5 \\
\hline 97901231 & 19790306 & 1,110 & 5.0 \\
\hline 97901232 & 19790418 & 720 & 7.5 \\
\hline 97901233 & 19790515 & 760 & 9.0 \\
\hline 97901234 & 19790611 & 450 & 20.0 \\
\hline 97901235 & 19790717 & 2,480 & 24.0 \\
\hline 97901236 & 19790822 & 1,120 & 24.5 \\
\hline 97901237 & 19790921 & 1,380 & 9.0 \\
\hline 98001350 & 19791004 & 1,410 & 15.5 \\
\hline 98001351 & 19791115 & 1,740 & 5.0 \\
\hline 98001352 & 19800205 & 1,470 & 1.0 \\
\hline 98001353 & 19800408 & 960 & 7.0 \\
\hline 98001354 & 19800506 & 1,070 & 10.0 \\
\hline 98001355 & 19800624 & 720 & 24.0 \\
\hline 98101268 & 19801006 & 1,100 & 20.0 \\
\hline 98101269 & 19801201 & 980 & - \\
\hline 98101270 & 19810114 & 870 & 1.5 \\
\hline 98101271 & 19810324 & 1,120 & 11.0 \\
\hline 98101272 & 19810421 & - & 11.0 \\
\hline 98101273 & 19810519 & 1,560 & 12.0 \\
\hline 98101274 & 19810624 & 1,630 & 16.0 \\
\hline 98101275 & 19810715 & 890 & 23.0 \\
\hline 98101276 & 19810903 & 1,120 & 14.5 \\
\hline 98200784 & 19811008 & 1,070 & 8.0 \\
\hline 98200785 & 19811117 & 920 & 4.5 \\
\hline 98200786 & 19811216 & 860 & 1.0 \\
\hline 98200787 & 19820114 & 960 & .5 \\
\hline 98200788 & 19820222 & 670 & 6.0 \\
\hline 98200789 & 19820331 & 850 & 6.0 \\
\hline 98200790 & 19820429 & 300 & 7.5 \\
\hline 98200791 & 19820520 & 290 & 11.0 \\
\hline
\end{tabular}


Table 9. Field measurements of specific conductance and water temperature at gaging station at Escalante River near Escalante (09337500, site 10), Garfield County, Utah, 1969-2001-Continued

\begin{tabular}{|c|c|c|c|}
\hline Record number & Date & $\begin{array}{c}\text { Specific } \\
\text { conductance } \\
(\mu \mathrm{S} / \mathrm{cm})\end{array}$ & $\begin{array}{c}\text { Water } \\
\text { temperature } \\
\left({ }^{\circ} \mathrm{C}\right)\end{array}$ \\
\hline 98200792 & 19820623 & 1,020 & 15.0 \\
\hline 98200793 & 19820722 & 1,580 & 17.0 \\
\hline 98200794 & 19820817 & 920 & 19.0 \\
\hline 98301032 & 19821007 & 1,210 & 6.0 \\
\hline 98301033 & 19821115 & 1,550 & 1.0 \\
\hline 98301034 & 19821228 & 630 & .5 \\
\hline 98301035 & 19830126 & 850 & 3.0 \\
\hline 98301036 & 19830307 & - & 7.0 \\
\hline 98301037 & 19830415 & 970 & 4.0 \\
\hline 98301038 & 19830518 & 810 & 5.0 \\
\hline 98301039 & 19830620 & 420 & - \\
\hline 98301040 & 19830809 & 650 & 26.0 \\
\hline 98401617 & 19831018 & 870 & 9.0 \\
\hline 98401618 & 19831207 & 760 & .5 \\
\hline 98401619 & 19840112 & 1,030 & 1.0 \\
\hline 98401620 & 19840209 & 810 & .5 \\
\hline 98401621 & 19840312 & 910 & 9.0 \\
\hline 98401622 & 19840412 & 1,270 & 6.0 \\
\hline 98401623 & 19840510 & 315 & 10.0 \\
\hline 98401624 & 19840613 & 710 & 12.0 \\
\hline 98401625 & 19840719 & 1,560 & 15.0 \\
\hline 98401626 & 19840822 & 600 & 17.0 \\
\hline 98601861 & 19851016 & 1,040 & 12.0 \\
\hline 98601862 & 19851129 & 1,080 & - \\
\hline 98601863 & 19860117 & 940 & 3.0 \\
\hline 98601864 & 19860311 & 930 & 9.0 \\
\hline 98601865 & 19860424 & 1,220 & 16.0 \\
\hline 98601866 & 19860602 & 1,040 & 15.0 \\
\hline 98601867 & 19860701 & 2,810 & 18.0 \\
\hline 98601868 & 19860818 & 1,810 & 27.0 \\
\hline 98700894 & 19870911 & 2,050 & 16.0 \\
\hline 98802107 & 19871008 & 2,070 & 7.0 \\
\hline 98802108 & 19871201 & - & 4.5 \\
\hline 98802109 & 19880210 & 1,260 & 4.0 \\
\hline 98802110 & 19880406 & - & 6.0 \\
\hline 98802111 & 19880505 & 1,060 & - \\
\hline 98802112 & 19880826 & 690 & 19.0 \\
\hline 98900145 & 19881004 & 1,940 & 15.5 \\
\hline 98900795 & 19881103 & 850 & 9.0 \\
\hline 98900796 & 19881207 & 1,140 & 8.0 \\
\hline 98902764 & 19890118 & 1,500 & - \\
\hline 98900797 & 19890129 & 1,120 & - \\
\hline 98900798 & 19890302 & 790 & 4.5 \\
\hline 98900799 & 19890404 & 1,100 & 19.0 \\
\hline 98900800 & 19890503 & 1,950 & 23.0 \\
\hline 98902453 & 19890607 & 2,270 & 26.0 \\
\hline 98902454 & 19890713 & 2,650 & 30.0 \\
\hline
\end{tabular}

\begin{tabular}{lccc}
\hline Record number & Date & $\begin{array}{c}\text { Specific } \\
\text { conductance } \\
(\mu \text { S/cm) }\end{array}$ & $\begin{array}{c}\text { Water } \\
\text { temperature } \\
\left({ }^{\circ} \mathbf{C}\right)\end{array}$ \\
\hline 98902455 & 19890811 & 2,300 & 25.0 \\
98902456 & 19890912 & 2,600 & 18.0 \\
99000225 & 19891005 & 2,680 & 18.0 \\
99000963 & 19891101 & 1,280 & 10.0 \\
99000964 & 19891207 & 2,300 & 2.0 \\
99002092 & 19900118 & 1,500 & - \\
99000966 & 19900223 & - & 10.0 \\
99000967 & 19900404 & 2,690 & 18.0 \\
99000968 & 19900426 & 2,440 & 14.0 \\
99001512 & 19900601 & - & 16.0 \\
99001513 & 19900717 & - & 23.0 \\
99002009 & 19900821 & 340 & 26.0 \\
99101217 & 19901129 & 2,500 & 7.0 \\
99101218 & 19910123 & 2,420 & 6.5 \\
99101219 & 19910220 & 2,410 & 10.0 \\
99101220 & 19910328 & 2,990 & 16.0 \\
99101221 & 19910424 & 2,890 & 12.0 \\
99101222 & 19910515 & 2,890 & 20.5 \\
99101223 & 19910618 & 4,350 & 23.0 \\
99101827 & 19910820 & 3,390 & 7.0 \\
00200308 & 20011023 & 1,400 & \\
\hline
\end{tabular}


Table 10. Physical properties and results of chemical analyses for water from the gaging station at Escalante River near Escalante (09337500, site 10), Garfield County, Utah, 1969-72

[Record number: A unique number that identifies one water-quality sample in the U.S. Geological Survey data base; See plate 1 for location of gaging station 09337500. Date: In year, month, day format; $\mathrm{ft} / \mathrm{s}$, cubic feet per second; $\mu \mathrm{S} / \mathrm{cm}$, microsiemens per centimeter at $25^{\circ}$ Celsius; ${ }^{\circ} \mathrm{C}$, degrees Celsius; $\mathrm{mg} / \mathrm{L}$, milligrams per liter; $\mu \mathrm{g} / \mathrm{L}$, micrograms per liter; —, no data]

\begin{tabular}{|c|c|c|c|c|c|c|c|c|}
\hline $\begin{array}{l}\text { Record } \\
\text { number }\end{array}$ & Date & $\begin{array}{c}\text { Discharge } \\
\left(\mathrm{ft}^{3} / \mathbf{s}\right)\end{array}$ & $\begin{array}{c}\text { pH, water, } \\
\text { whole, field, } \\
\text { (standard } \\
\text { units) }\end{array}$ & $\begin{array}{c}\text { Specific } \\
\text { conduc- } \\
\text { tance } \\
(\mu \mathrm{S} / \mathrm{cm})\end{array}$ & $\begin{array}{c}\text { Temper- } \\
\text { ature, } \\
\text { water } \\
\left({ }^{\circ} \mathrm{C}\right)\end{array}$ & $\begin{array}{c}\text { Hardness, } \\
\text { total } \\
(\mathrm{mg} / \mathrm{L} \text { as } \\
\left.\mathrm{CaCO}_{3}\right)\end{array}$ & $\begin{array}{c}\text { Calcium, } \\
\text { dissolved } \\
\text { (mg/L } \\
\text { as Ca) }\end{array}$ & $\begin{array}{c}\text { Magnesium, } \\
\text { dissolved } \\
\text { (mg/L } \\
\text { as } \mathbf{M g} \text { ) }\end{array}$ \\
\hline 96900542 & 19690805 & 30.2 & 7.6 & 3,260 & 26.0 & 1,900 & 587 & 101 \\
\hline 96900545 & 19690806 & 143 & 7.9 & 931 & 22.0 & 290 & 29.0 & 52.0 \\
\hline 97000374 & 19691211 & 18 & 7.9 & 831 & 0.0 & 330 & 75.0 & 35.0 \\
\hline 97000375 & 19700415 & 24.4 & 8.3 & 731 & 14.0 & 260 & 63.0 & 24.0 \\
\hline 97100376 & 19701112 & 15 & 8.0 & 845 & 7.0 & 300 & 75.0 & 27.0 \\
\hline 97100377 & 19710406 & 18 & 8.5 & 700 & 16.0 & - & - & - \\
\hline 97200868 & 19711203 & 20 & 8.1 & 915 & 1.5 & 320 & 79.0 & 31.0 \\
\hline 97200870 & 19720606 & 10 & 7.4 & 625 & 26.0 & 230 & 57.0 & 22.0 \\
\hline
\end{tabular}

\begin{tabular}{|c|c|c|c|c|c|c|c|c|c|}
\hline $\begin{array}{l}\text { Record } \\
\text { number }\end{array}$ & $\begin{array}{c}\text { Sodium, } \\
\text { dissolved } \\
\text { (mg/L as Na) }\end{array}$ & $\begin{array}{l}\text { Alkalinity, } \\
\text { water, } \\
\text { unfiltered, } \\
\text { field } \\
\text { (mg/L as } \\
\left.\mathrm{CaCO}_{3}\right)\end{array}$ & $\begin{array}{c}\text { Chloride, } \\
\text { dissolved } \\
\text { (mg/L as } \\
\text { CI) }\end{array}$ & $\begin{array}{c}\text { Fluoride, } \\
\text { dissolved } \\
\text { (mg/L as } \\
\text { F) }\end{array}$ & $\begin{array}{c}\text { Silica, } \\
\text { dissolved } \\
(\mathrm{mg} / \mathrm{L} \text { as } \\
\left.\mathrm{SiO}_{2}\right)\end{array}$ & $\begin{array}{c}\text { Sulfate, } \\
\text { dissolved } \\
(\mathrm{mg} / \mathrm{L} \text { as } \\
\left.\mathrm{SO}_{4}\right)\end{array}$ & $\begin{array}{l}\text { Solids, } \\
\text { residue at } \\
180^{\circ} \mathrm{C}, \\
\text { dissolved } \\
\text { (mg/L) }\end{array}$ & $\begin{array}{l}\text { Solids, sum of } \\
\text { constituents, } \\
\text { dissolved } \\
\text { (mg/L) }\end{array}$ & $\begin{array}{c}\text { Boron, } \\
\text { dissolved } \\
(\mu \mathrm{g} / \mathrm{L} \text { as } \mathrm{B})\end{array}$ \\
\hline 96900542 & 205 & 153 & 90.0 & - & 14.0 & 2,030 & 3,240 & 3,140 & - \\
\hline 96900545 & 114 & 354 & 17.0 & - & 11.0 & 176 & 619 & 615 & - \\
\hline 97000374 & 53.0 & 203 & 64.0 & - & - & 160 & 552 & 511 & - \\
\hline 97000375 & 54.0 & 164 & 64.0 & - & - & 130 & 456 & 437 & - \\
\hline 97100376 & 56.0 & 171 & 50.0 & - & 20.0 & 164 & 561 & 498 & - \\
\hline 97100377 & - & - & - & - & - & - & - & - & - \\
\hline 97200868 & 65.0 & 168 & 73.0 & - & - & 180 & - & 533 & - \\
\hline 97200870 & 38.0 & 123 & 49.0 & .4 & 12.0 & 120 & - & 377 & 60 \\
\hline
\end{tabular}


Table 11. Physical properties and results of chemical analyses for water from the gaging station at Escalante River at mouth (09339500, site 64), Kane County, Utah, 1951-53

[Record number: A unique number that identifies one water-quality sample in the U.S. Geological Survey data base. See plate 1 for location of station 09339500; Date: In year, month, day format; $\mathrm{ft}^{3} / \mathrm{s}$, cubic feet per second; $\mu \mathrm{S} / \mathrm{cm}$, microsiemens per centimeter at $25^{\circ} \mathrm{Celsius} ; \mathrm{mg} / \mathrm{L}, \mathrm{milligrams} \mathrm{per} \mathrm{liter;} \mu \mathrm{g} / \mathrm{L}$, micrograms per liter; —, no data]

\begin{tabular}{|c|c|c|c|c|c|c|c|c|}
\hline $\begin{array}{l}\text { Record } \\
\text { number }\end{array}$ & Date & $\begin{array}{c}\text { Discharge, } \\
\text { daily mean } \\
\qquad\left(\mathrm{ft}^{3} / \mathrm{s}\right)\end{array}$ & $\begin{array}{c}\text { Specific } \\
\text { conductance } \\
(\mu S / \mathrm{cm})\end{array}$ & $\begin{array}{l}\text { pH, water, whole } \\
\text { (standard units) }\end{array}$ & $\begin{array}{c}\text { Hardness, } \\
\text { total } \\
(\mathrm{mg} / \mathrm{L} \text { as } \\
\left.\mathrm{CaCO}_{3}\right)\end{array}$ & $\begin{array}{c}\text { Calcium, } \\
\text { dissolved } \\
\text { (mg/L as Ca) }\end{array}$ & $\begin{array}{l}\text { Magnesium, } \\
\text { dissolved } \\
\text { (mg/L as } \mathrm{Mg})\end{array}$ & $\begin{array}{c}\text { Potassium, } \\
\text { dissolved } \\
\text { (mg/L as K) }\end{array}$ \\
\hline 95100392 & 19510301 & 83 & 490 & 7.7 & 200 & 50.0 & 19.0 & 4.00 \\
\hline 95100393 & 19510311 & 67 & 491 & 7.6 & 200 & 50.0 & 19.0 & 3.80 \\
\hline 95100394 & 19510321 & 60 & 506 & 7.3 & 210 & 50.0 & 20.0 & 4.30 \\
\hline 95100395 & 19510401 & 85 & 528 & 7.4 & 220 & 52.0 & 22.0 & 5.10 \\
\hline 95100396 & 19510411 & 32 & 552 & 7.8 & 230 & 52.0 & 24.0 & 7.00 \\
\hline 95100397 & 19510421 & 49 & 546 & 7.8 & 220 & 52.0 & 23.0 & 5.30 \\
\hline 95100398 & 19510501 & 59 & 558 & 7.8 & 230 & 52.0 & 24.0 & 5.60 \\
\hline 95100399 & 19510511 & 35 & 548 & 7.5 & 230 & 56.0 & 21.0 & 4.00 \\
\hline 95100400 & 19510521 & 45 & 460 & 7.7 & 200 & 50.0 & 17.0 & 5.10 \\
\hline 95100402 & 19510601 & 81 & 498 & 7.7 & 200 & 50.0 & 19.0 & 4.80 \\
\hline 95100403 & 19510611 & 27 & 633 & 7.7 & 250 & 56.0 & 26.0 & 6.10 \\
\hline 95100404 & 19510621 & 17 & 643 & 7.6 & 250 & 54.0 & 28.0 & 5.90 \\
\hline 95100405 & 19510701 & 15 & 651 & 7.8 & 240 & 48.0 & 30.0 & 5.60 \\
\hline 95100406 & 19510711 & 7.2 & 624 & 7.8 & 240 & 48.0 & 28.0 & 6.40 \\
\hline 95100407 & 19510721 & 14 & 703 & 7.8 & 250 & 57.0 & 27.0 & 7.50 \\
\hline 95100408 & 19510801 & 33 & 713 & 7.7 & 300 & 82.0 & 23.0 & 11.0 \\
\hline 95100409 & 19510811 & 38 & 690 & 7.8 & 290 & 72.0 & 26.0 & 8.80 \\
\hline 95100410 & 19510821 & 50 & 635 & 7.7 & 280 & 77.0 & 22.0 & 8.80 \\
\hline 95100411 & 19510901 & 100 & 619 & 7.8 & 240 & 60.0 & 22.0 & 7.20 \\
\hline 95100412 & 19510911 & 34 & 629 & 7.9 & 260 & 64.0 & 24.0 & 5.80 \\
\hline 95100413 & 19510921 & 34 & 597 & 7.9 & 240 & 61.0 & 22.0 & 4.80 \\
\hline 95200449 & 19511001 & 51 & 572 & 7.9 & 230 & 60.0 & 20.0 & 6.20 \\
\hline 95200450 & 19511011 & 38 & 586 & 8.0 & 240 & 60.0 & 23.0 & 4.30 \\
\hline 95200451 & 19511101 & 88 & 514 & 7.8 & 230 & 56.0 & 21.0 & 3.80 \\
\hline 95200452 & 19511111 & 55 & 542 & 7.8 & 230 & 54.0 & 23.0 & 2.20 \\
\hline 95200453 & 19511121 & 69 & 457 & 7.9 & 200 & 50.0 & 19.0 & 2.00 \\
\hline 95200454 & 19511201 & 100 & 493 & 7.9 & 220 & 52.0 & 22.0 & 2.20 \\
\hline 95200455 & 19511211 & 19 & 524 & 7.5 & 240 & 58.0 & 24.0 & 3.40 \\
\hline 95200456 & 19520101 & 168 & 546 & 8.0 & 240 & 58.0 & 24.0 & 4.40 \\
\hline 95200457 & 19520111 & 40 & 546 & - & 230 & 55.0 & 23.0 & 3.60 \\
\hline 95200458 & 19520127 & 207 & 472 & - & 180 & 46.0 & 17.0 & 4.00 \\
\hline 95200459 & 19520201 & 119 & 480 & 7.8 & 200 & 48.0 & 19.0 & 3.60 \\
\hline 95200460 & 19520219 & 107 & 487 & 7.9 & 210 & 48.0 & 21.0 & 3.00 \\
\hline
\end{tabular}


Table 11. Physical properties and results of chemical analyses for water from the gaging station at Escalante River at mouth (09339500, site 64), Kane County, Utah, 1951-53-Continued

\begin{tabular}{|c|c|c|c|c|c|c|c|}
\hline $\begin{array}{c}\text { Sodium, } \\
\text { dissolved } \\
\text { (mg/L as } \mathrm{Na})\end{array}$ & $\begin{array}{c}\text { Chloride, } \\
\text { dissolved } \\
\text { (mg/L as CI) }\end{array}$ & $\begin{array}{c}\text { Fluoride, } \\
\text { dissolved } \\
\text { (mg/L as F) }\end{array}$ & $\begin{array}{l}\text { Silica, dissolved } \\
\text { (mg/L as } \mathrm{SiO}_{2} \text { ) }\end{array}$ & $\begin{array}{c}\text { Sulfate, } \\
\text { dissolved } \\
\left(\mathrm{mg} / \mathrm{L} \text { as } \mathrm{SO}_{4}\right)\end{array}$ & $\begin{array}{c}\text { Solids, residue at } \\
180^{\circ} \mathrm{C} \text {, dissolved } \\
\text { (mg/L) }\end{array}$ & $\begin{array}{l}\text { Solids, sum of } \\
\text { constituents, } \\
\text { dissolved } \\
\text { (mg/L) }\end{array}$ & $\begin{array}{c}\text { Boron, dissolved } \\
(\mu \mathrm{g} / \mathrm{L} \text { as B })\end{array}$ \\
\hline 23.0 & 26.0 & 0.3 & 22.0 & 72.0 & 301 & 301 & - \\
\hline 24.0 & 28.0 & .3 & 21.0 & 75.0 & 308 & 306 & - \\
\hline 25.0 & 28.0 & .1 & 20.0 & 80.0 & 330 & 314 & - \\
\hline 27.0 & 31.0 & .2 & 18.0 & 88.0 & 339 & 331 & - \\
\hline 28.0 & 33.0 & .2 & 17.0 & 95.0 & 349 & 345 & - \\
\hline 28.0 & 33.0 & .2 & 16.0 & 91.0 & 344 & 337 & - \\
\hline 30.0 & 35.0 & .2 & 14.0 & 97.0 & 356 & 345 & - \\
\hline 28.0 & 28.0 & .2 & 18.0 & 89.0 & 344 & 337 & - \\
\hline 21.0 & 21.0 & .3 & 18.0 & 59.0 & 284 & 283 & - \\
\hline 27.0 & 29.0 & .3 & 18.0 & 77.0 & 308 & 310 & - \\
\hline 35.0 & 41.0 & .3 & 19.0 & 117 & 398 & 388 & - \\
\hline 36.0 & 44.0 & .4 & 16.0 & 124 & 401 & 395 & - \\
\hline 37.0 & 46.0 & .4 & 15.0 & 132 & 410 & 393 & - \\
\hline 36.0 & 45.0 & .4 & 19.0 & 126 & 394 & 385 & - \\
\hline 43.0 & 42.0 & .4 & 21.0 & 136 & 453 & 430 & - \\
\hline 34.0 & 22.0 & .3 & 16.0 & 174 & 495 & 471 & - \\
\hline 35.0 & 36.0 & .3 & 19.0 & 150 & 470 & 446 & - \\
\hline 27.0 & 22.0 & .3 & 14.0 & 146 & 431 & 415 & - \\
\hline 33.0 & 22.0 & .3 & 14.0 & 136 & 410 & 387 & - \\
\hline 32.0 & 34.0 & .2 & 20.0 & 130 & 411 & 403 & - \\
\hline 31.0 & 32.0 & .2 & 17.0 & 123 & 385 & 379 & - \\
\hline 30.0 & 29.0 & .2 & 15.0 & 115 & 370 & 362 & - \\
\hline 29.0 & 33.0 & .2 & 16.0 & 117 & 377 & 371 & 90 \\
\hline 23.0 & 26.0 & .2 & 15.0 & 92.0 & 326 & 322 & - \\
\hline 26.0 & 31.0 & .1 & 18.0 & 98.0 & 344 & 339 & 140 \\
\hline 21.0 & 25.0 & .3 & 16.0 & 80.0 & 288 & 290 & - \\
\hline 24.0 & 26.0 & .4 & 18.0 & 82.0 & 308 & 315 & - \\
\hline 24.0 & 30.0 & .2 & 20.0 & 87.0 & 336 & 339 & 160 \\
\hline 29.0 & 26.0 & .2 & 19.0 & 94.0 & 351 & 358 & - \\
\hline 28.0 & 29.0 & - & 22.0 & 90.0 & 370 & 344 & - \\
\hline 29.0 & 22.0 & .3 & 17.0 & 78.0 & 309 & 295 & - \\
\hline 26.0 & 22.0 & .3 & 18.0 & 76.0 & 316 & 300 & 50 \\
\hline 24.0 & 24.0 & .3 & 19.0 & 81.0 & 324 & 305 & - \\
\hline
\end{tabular}


Table 11. Physical properties and results of chemical analyses for water from the gaging station at Escalante River at mouth (09339500, site 64), Kane County, Utah, 1951-53-Continued

\begin{tabular}{|c|c|c|c|c|c|c|c|c|}
\hline $\begin{array}{l}\text { Record } \\
\text { number }\end{array}$ & Date & $\begin{array}{c}\text { Discharge, } \\
\text { daily mean } \\
\left(\mathrm{ft}^{3} / \mathrm{s}\right)\end{array}$ & $\begin{array}{c}\text { Specific } \\
\text { conductance } \\
(\mu \mathrm{S} / \mathrm{cm})\end{array}$ & $\begin{array}{l}\text { pH, water, whole } \\
\text { (standard units) }\end{array}$ & $\begin{array}{c}\text { Hardness, } \\
\text { total } \\
(\mathrm{mg} / \mathrm{L} \text { as } \\
\left.\mathrm{CaCO}_{3}\right)\end{array}$ & $\begin{array}{c}\text { Calcium, } \\
\text { dissolved } \\
\text { (mg/L as Ca) }\end{array}$ & $\begin{array}{l}\text { Magnesium, } \\
\text { dissolved } \\
\text { (mg/L as } \mathrm{Mg})\end{array}$ & $\begin{array}{c}\text { Potassium, } \\
\text { dissolved } \\
\text { (mg/L as K) }\end{array}$ \\
\hline 95200461 & 19520301 & 162 & 474 & 7.9 & 190 & 45.0 & 18.0 & 4.50 \\
\hline 95200462 & 19520311 & 132 & 476 & 8.0 & 200 & 46.0 & 20.0 & 3.50 \\
\hline 95200463 & 19520321 & 98 & 486 & 7.6 & 200 & 48.0 & 20.0 & 3.80 \\
\hline 95200464 & 19520401 & 207 & 481 & 7.8 & 190 & 45.0 & 19.0 & 3.80 \\
\hline 95200465 & 19520411 & 98 & 486 & 7.9 & 200 & 46.0 & 20.0 & 3.60 \\
\hline 95200466 & 19520421 & 132 & 418 & 7.9 & 170 & 40.0 & 18.0 & 4.00 \\
\hline 95200467 & 19520501 & 110 & 412 & 7.7 & 180 & 44.0 & 17.0 & 4.20 \\
\hline 95200468 & 19520511 & 179 & 332 & 7.8 & 150 & 41.0 & 12.0 & 3.00 \\
\hline 95200469 & 19520521 & 83 & 429 & 7.8 & 180 & 44.0 & 17.0 & 3.30 \\
\hline 95200470 & 19520604 & 505 & 367 & 7.9 & 150 & 38.0 & 13.0 & 5.00 \\
\hline 95200471 & 19520611 & 81 & 493 & 7.9 & 200 & 49.0 & 20.0 & 4.00 \\
\hline 95200472 & 19520621 & 26 & 617 & 7.9 & 250 & 56.0 & 26.0 & 4.90 \\
\hline 95200473 & 19520701 & 31 & 635 & 7.8 & 250 & 56.0 & 26.0 & 5.80 \\
\hline 95200475 & 19520714 & 32 & 694 & 7.8 & 280 & 68.0 & 26.0 & 6.60 \\
\hline 95200476 & 19520721 & 25 & 705 & 7.6 & 290 & 72.0 & 27.0 & 5.80 \\
\hline 95200477 & 19520801 & 72 & 751 & 7.6 & 300 & 76.0 & 26.0 & 6.50 \\
\hline 95200478 & 19520811 & 30 & 772 & 7.6 & 320 & 88.0 & 25.0 & 6.50 \\
\hline 95200479 & 19520821 & 107 & 810 & 7.5 & 370 & 98.0 & 30.0 & 7.80 \\
\hline 95200481 & 19520904 & 45 & 753 & 7.9 & 320 & 82.0 & 27.0 & 5.90 \\
\hline 95200482 & 19520912 & 49 & 663 & 8.1 & 280 & 75.0 & 22.0 & 5.70 \\
\hline 95200483 & 19520923 & 379 & 564 & 8.0 & 260 & 63.0 & 24.0 & 4.80 \\
\hline 95300298 & 19521011 & 49 & 622 & 8.1 & 260 & 68.0 & 21.0 & - \\
\hline 95300300 & 19521021 & 71 & 549 & 7.6 & 240 & 59.0 & 22.0 & 5.20 \\
\hline 95300302 & 19521114 & 74 & 593 & 7.4 & 260 & 75.0 & 17.0 & - \\
\hline 95300303 & 19521220 & 122 & 474 & 7.3 & 200 & 52.0 & 16.0 & - \\
\hline 95300304 & 19530107 & 95 & 474 & 7.3 & 190 & 49.0 & 16.0 & - \\
\hline 95300305 & 19530219 & 88 & 442 & 7.4 & 180 & 49.0 & 15.0 & - \\
\hline 95300308 & 19530411 & 48 & 547 & 7.7 & 220 & 64.0 & 13.0 & - \\
\hline 95300311 & 19530511 & 49 & 574 & 8.0 & 220 & 55.0 & 21.0 & - \\
\hline 95300314 & 19530611 & 40 & 591 & 7.8 & 230 & 52.0 & 23.0 & - \\
\hline 95300316 & 19530701 & 26 & 594 & 7.9 & 220 & 50.0 & 24.0 & - \\
\hline 95300317 & 19530720 & 50 & 787 & - & - & - & - & - \\
\hline 95300318 & 19530801 & 662 & 778 & - & - & - & - & - \\
\hline 95300319 & 19530821 & 27 & 1160 & - & - & - & - & - \\
\hline 95300321 & 19530911 & 53 & 881 & 8.0 & 420 & 117 & 30.0 & - \\
\hline
\end{tabular}


Table 11. Physical properties and results of chemical analyses for water from the gaging station at Escalante River at mouth (09339500, site 64), Kane County, Utah, 1951-53-Continued

\begin{tabular}{|c|c|c|c|c|c|c|c|}
\hline $\begin{array}{c}\text { Sodium, } \\
\text { dissolved } \\
\text { (mg/L as } \mathrm{Na})\end{array}$ & $\begin{array}{l}\text { Chloride, } \\
\text { dissolved } \\
\text { (mg/L as Cl) }\end{array}$ & $\begin{array}{c}\text { Fluoride, } \\
\text { dissolved } \\
\text { (mg/L as F) }\end{array}$ & $\begin{array}{l}\text { Silica, dissolved } \\
\left(\mathrm{mg} / \mathrm{L} \text { as } \mathrm{SiO}_{2}\right)\end{array}$ & $\begin{array}{c}\text { Sulfate, } \\
\text { dissolved } \\
\left(\mathrm{mg} / \mathrm{L} \text { as } \mathrm{SO}_{4}\right)\end{array}$ & $\begin{array}{c}\text { Solids, residue at } \\
180^{\circ} \mathrm{C} \text {, dissolved } \\
\text { (mg/L) }\end{array}$ & $\begin{array}{l}\text { Solids, sum of } \\
\text { constituents, } \\
\text { dissolved } \\
\text { (mg/L) }\end{array}$ & $\begin{array}{c}\text { Boron, dissolved } \\
\quad(\mu \mathrm{g} / \mathrm{L} \text { as } \mathrm{B})\end{array}$ \\
\hline 30.0 & 21.0 & 0.3 & 16.0 & 76.0 & 309 & 296 & - \\
\hline 26.0 & 24.0 & .3 & 19.0 & 76.0 & 318 & 298 & 50 \\
\hline 27.0 & 27.0 & .1 & 16.0 & 82.0 & 310 & 307 & - \\
\hline 30.0 & 22.0 & .1 & 16.0 & 76.0 & 304 & 302 & - \\
\hline 27.0 & 26.0 & .2 & 18.0 & 74.0 & 313 & 303 & 70 \\
\hline 21.0 & 19.0 & .2 & 17.0 & 60.0 & 268 & 259 & - \\
\hline 17.0 & 18.0 & .3 & 22.0 & 52.0 & 263 & 257 & - \\
\hline 12.0 & 13.0 & .3 & 17.0 & 38.0 & 208 & 207 & 60 \\
\hline 21.0 & 24.0 & .3 & 21.0 & 65.0 & 273 & 273 & - \\
\hline 20.0 & 14.0 & .4 & 20.0 & 42.0 & 236 & 228 & - \\
\hline 26.0 & 30.0 & .4 & 21.0 & 75.0 & 310 & 308 & - \\
\hline 33.0 & 42.0 & .2 & 18.0 & 117 & 396 & 384 & - \\
\hline 36.0 & 42.0 & .3 & 18.0 & 132 & 412 & 400 & - \\
\hline 36.0 & 40.0 & .3 & 25.0 & 142 & 446 & 443 & 150 \\
\hline 38.0 & 39.0 & .3 & 22.0 & 138 & 464 & 448 & - \\
\hline 45.0 & 35.0 & .4 & 19.0 & 162 & 500 & 484 & - \\
\hline 41.0 & 35.0 & .4 & 17.0 & 173 & 511 & 499 & 20 \\
\hline 35.0 & 24.0 & .4 & 18.0 & 193 & 560 & 536 & - \\
\hline 37.0 & 40.0 & .2 & 19.0 & 160 & 492 & 481 & - \\
\hline 29.0 & 34.0 & .2 & 16.0 & 128 & 426 & 413 & 70 \\
\hline 26.0 & 26.0 & .2 & 16.0 & 114 & 362 & 365 & - \\
\hline 29.0 & 35.0 & - & 21.0 & 121 & 404 & - & 110 \\
\hline 24.0 & 24.0 & .3 & 15.0 & 101 & 344 & 340 & - \\
\hline 24.0 & 26.0 & - & 14.0 & 101 & 370 & - & - \\
\hline 22.0 & - & - & 28.0 & - & 302 & - & - \\
\hline 21.0 & 22.0 & - & 28.0 & 74.0 & 285 & - & - \\
\hline 20.0 & - & - & - & - & 267 & - & - \\
\hline 26.0 & 32.0 & - & 18.0 & 83.0 & 335 & - & - \\
\hline 30.0 & 34.0 & - & 16.0 & 91.0 & 354 & - & - \\
\hline 33.0 & 39.0 & - & 17.0 & 110 & 366 & - & \\
\hline 33.0 & 40.0 & - & 18.0 & 114 & 372 & - & 120 \\
\hline- & - & - & - & - & 532 & - & - \\
\hline- & - & - & - & - & 540 & - & - \\
\hline- & - & - & - & - & 900 & - & - \\
\hline 35.0 & 31.0 & - & 20.0 & 255 & 641 & - & - \\
\hline
\end{tabular}


Table 12. Physical properties and results of chemical analyses for water from selected surface-water sites and springs in the Escalante River drainage basin, Garfield and Kane Counties, Utah, 1981-2002

[Site number: See plate 1 for location of site where chemical analyses data have been collected; Site description or local name: See numbering system used for hydrologic-data sites in Utah, see table 1 for complete description of site; Record number: A unique number that identifies one water-quality sample in the U.S. Geological Survey database; Date: In month, day, year format; $\mathrm{ft} / \mathrm{s}$, cubic feet per second; $\mu \mathrm{S} / \mathrm{cm}$, microsiemens per centimeter at $25^{\circ} \mathrm{Celsius,}{ }^{\circ} \mathrm{C}$, degrees Celsius; mg/L, milligrams per liter; $\mu \mathrm{g} / \mathrm{L}$, micrograms per liter; BLM, Bureau of Land Management; —, no data; <, less than; E, estimated; mi, mile]

\begin{tabular}{|c|c|c|c|c|c|c|c|c|c|c|c|}
\hline $\begin{array}{c}\text { Site } \\
\text { num- } \\
\text { ber }\end{array}$ & Site description or local name & $\begin{array}{l}\text { Record } \\
\text { number }\end{array}$ & Date & $\begin{array}{c}\text { Discharge, } \\
\text { instant- } \\
\text { aneous } \\
\left(\mathrm{ft}^{3} / \mathrm{s}\right)\end{array}$ & $\begin{array}{c}\text { Specific } \\
\text { conduc- } \\
\text { tance, } \\
\text { lab } \\
(\mu \mathrm{S} / \mathrm{cm})\end{array}$ & $\begin{array}{c}\text { pH, } \\
\text { water, } \\
\text { whole, } \\
\text { field } \\
\text { (standard } \\
\text { units) }\end{array}$ & $\begin{array}{c}\text { pH, water, } \\
\text { whole, lab } \\
\text { (standard } \\
\text { units) }\end{array}$ & $\begin{array}{c}\text { Specific } \\
\text { conduc- } \\
\text { tance } \\
(\mu \mathrm{S} / \mathrm{cm})\end{array}$ & $\begin{array}{c}\text { Temper- } \\
\text { ature, } \\
\text { water } \\
\left({ }^{\circ} \mathrm{C}\right)\end{array}$ & $\begin{array}{c}\text { Hardness, } \\
\text { total } \\
\text { (mg/L as } \\
\left.\mathrm{CaCO}_{3}\right)\end{array}$ & $\begin{array}{c}\text { Calcium, } \\
\text { dissolved } \\
\text { (mg/L as } \\
\text { Ca) }\end{array}$ \\
\hline \multicolumn{12}{|c|}{ SURFACE-WATER SITES } \\
\hline \multirow[t]{2}{*}{2} & \multirow{2}{*}{$\begin{array}{l}\text { Birch Creek } 10.5 \text { mi above } \\
\text { confluence with North Creek }\end{array}$} & 98102979 & $04-20-81$ & 1.4 & 332 & 8.5 & 8.2 & - & 10.0 & 160 & 36.0 \\
\hline & & 98102980 & $08-25-81$ & 1.1 & 327 & 8.7 & 8.7 & 280 & 18.0 & 160 & 29.0 \\
\hline \multirow[t]{3}{*}{4} & \multirow[t]{3}{*}{ Upper Valley Creek near Liston Flat } & 98102958 & $04-21-81$ & 0.73 & 1,340 & 8.5 & 8.2 & 1,400 & 9.5 & 360 & 63.0 \\
\hline & & 98102959 & $08-25-81$ & .36 & 1,090 & 8.6 & 8.4 & 1,140 & 27.5 & 280 & 34.0 \\
\hline & & 98202199 & $03-03-82$ & 1.6 & 1,260 & 8.5 & 8.7 & 980 & 9.5 & 390 & 62.0 \\
\hline \multirow[t]{3}{*}{6} & \multirow{3}{*}{$\begin{array}{l}\text { Birch Creek } 0.8 \text { mi above confluence } \\
\quad \text { with North Creek }\end{array}$} & 98102969 & $04-20-81$ & 2.6 & 459 & 8.6 & 8.3 & 465 & 20.5 & 240 & 47.0 \\
\hline & & 98102970 & $08-25-81$ & 1.8 & 426 & 8.5 & 8.3 & 435 & 24.5 & 220 & 39.0 \\
\hline & & 98202213 & $05-05-82$ & 5.6 & 391 & 8.1 & 8.4 & 375 & 18.0 & 190 & 41.0 \\
\hline 19 & Escalante River below Calf Creek & 00200645 & 08-21-02 & - & - & 8.3 & - & 450 & 19.5 & 190 & 47.8 \\
\hline 20 & Escalante River above Boulder Creek & 98202211 & $10-21-81$ & 43.9 & 721 & 8.5 & 8.2 & 680 & 12.5 & 280 & 64.0 \\
\hline 25 & Boulder Creek at mouth & 98202212 & $10-21-81$ & 41.2 & 266 & 8.6 & 8.1 & 280 & 10.0 & 130 & 35.0 \\
\hline \multirow[t]{2}{*}{35} & Alvey Wash above Coal Bed Canyon & 98202203 & $11-15-81$ & .1 & 1,220 & 8.2 & 7.9 & 1,230 & 3.5 & 690 & 139 \\
\hline & & 98202204 & $03-03-82$ & .12 & 1,220 & 8.4 & 8.6 & 1,070 & 14.0 & 620 & 125 \\
\hline 39 & Escalante River above Fence Canyon & 98202183 & $10-22-81$ & 78.9 & 512 & 8.5 & 8.2 & 510 & 13.5 & 220 & 53.0 \\
\hline 42 & Left Hand Collett Canyon & 98202156 & $03-03-82$ & .27 & 3,300 & 8.1 & 8.2 & 3,490 & 11.0 & 2,300 & 300 \\
\hline 50 & Scorpion Gulch near mouth & 00100638 & $05-22-01$ & - & 306 & - & 8.0 & 299 & 13.5 & 160 & 39.0 \\
\hline 61 & Stevens Canyon near mouth & 00100640 & $05-24-01$ & - & 401 & - & 7.8 & 401 & 15.5 & 170 & 35.6 \\
\hline \multicolumn{12}{|c|}{ SPRINGS } \\
\hline S1 & $(\mathrm{C}-34-1) 24 \mathrm{ccc}-\mathrm{S} 1$ & 98202222 & $11-13-81$ & - & 560 & 7.3 & 7.6 & 580 & 8.0 & 320 & 69.0 \\
\hline S13 & (D-37-1)10acd-S1 & 98202177 & $10-25-81$ & .02 & 934 & 7.2 & 7.6 & 1,010 & 8.5 & 550 & 128 \\
\hline S14 & (D-37-3) 6aaa-S1 & 98202186 & $10-19-81$ & $<.01$ & 1,470 & 8.1 & 8.1 & 1,540 & 11.5 & 880 & 140 \\
\hline S15 & (D-36-2)13aad-S1 & 98202197 & $10-20-81$ & $<.01$ & 606 & 7.4 & 7.8 & 670 & 7.0 & 350 & 82.0 \\
\hline S16 & (D-37-2)36cbc-S1 & 98202162 & $10-19-81$ & $<.01$ & 3,670 & 7.0 & 8.0 & 4,070 & 12.5 & 2,100 & 330 \\
\hline S17 & (D-38-3)17bda-S1 & 98202155 & $11-14-81$ & $<.01$ & 630 & 8.0 & 8.3 & 680 & 8.5 & 360 & 69.0 \\
\hline S18 & $(\mathrm{D}-38-3) 14 \mathrm{cbc}-\mathrm{S} 1$ & 98202154 & $10-19-81$ & $<.01$ & 1,680 & 7.8 & 8.1 & 1,620 & 12.5 & 790 & 120 \\
\hline S19 & (D-38-3)11aad-S1 & 98202158 & $11-14-81$ & $<.01$ & 974 & 8.1 & 8.3 & 980 & 11.0 & 480 & 48.0 \\
\hline S21 & (D-38-8) 8ada-S1 & 00101634 & $05-22-01$ & - & 145 & - & 7.7 & 142 & 16.5 & 67 & 15.5 \\
\hline $\mathrm{S} 23$ & (D-38-8) 4dbc-S1 & 00100639 & $05-22-01$ & - & 524 & - & 7.8 & 508 & 13.5 & 260 & 53.9 \\
\hline S24 & (D-39-8)13bab-S1 & 00100641 & $05-24-01$ & - & 163 & - & 8.2 & 168 & 20.5 & 79 & 17.1 \\
\hline
\end{tabular}

${ }^{1}$ Filtered lab alkalinity. 
Table 12. Physical properties and results of chemical analyses for water from selected surface-water and spring sites in the Escalante River drainage basin, Garfield and Kane Counties, Utah, 1981-2002-Continued

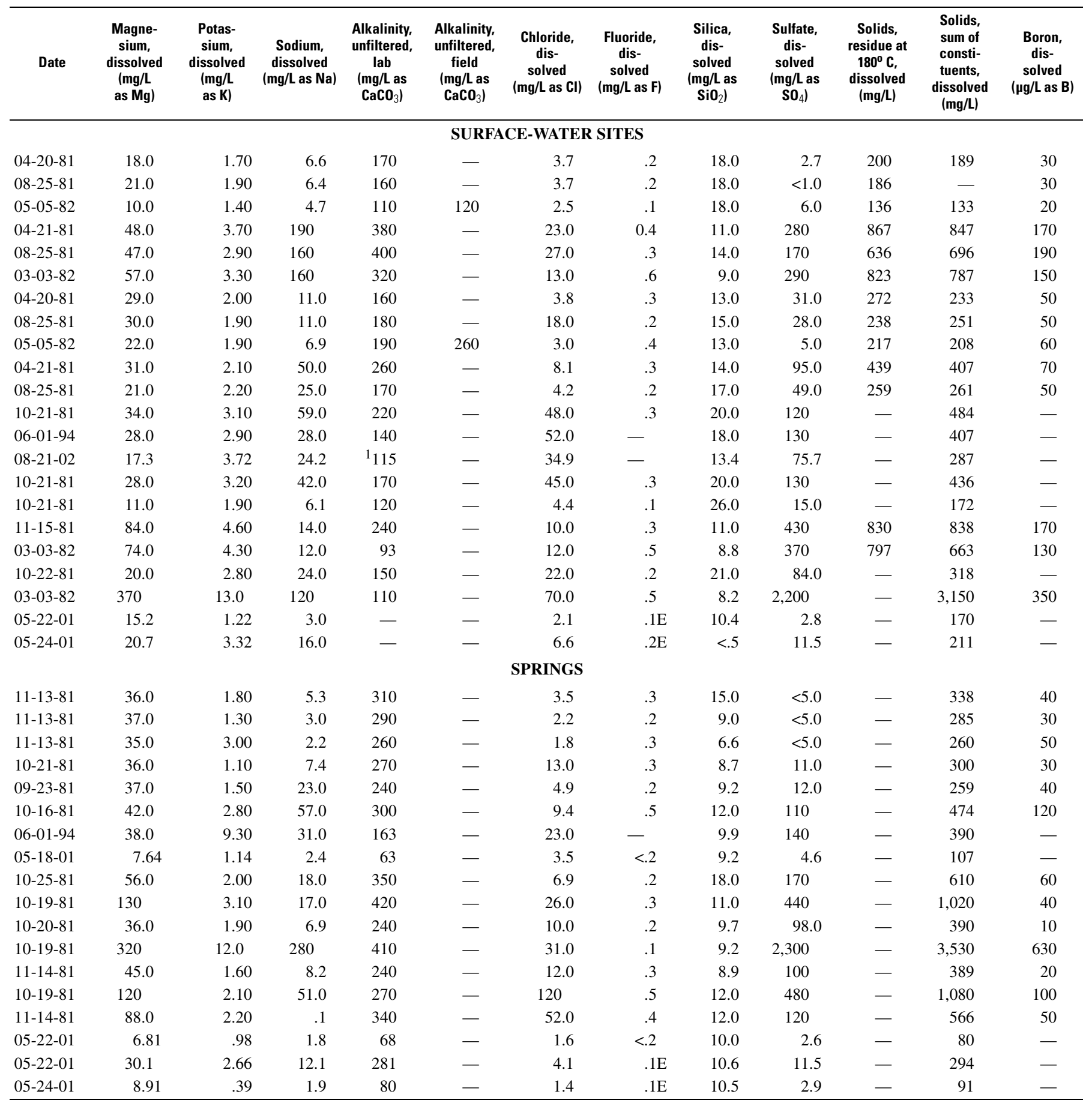

